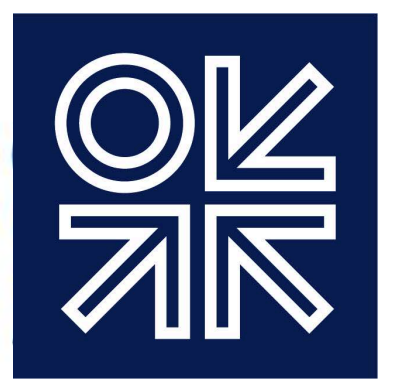

THE OXFORD

INSTITUTE

FOR ENERGY

STUDIES

April 2019

\title{
Price reviews and arbitrations in Asian LNG markets
}

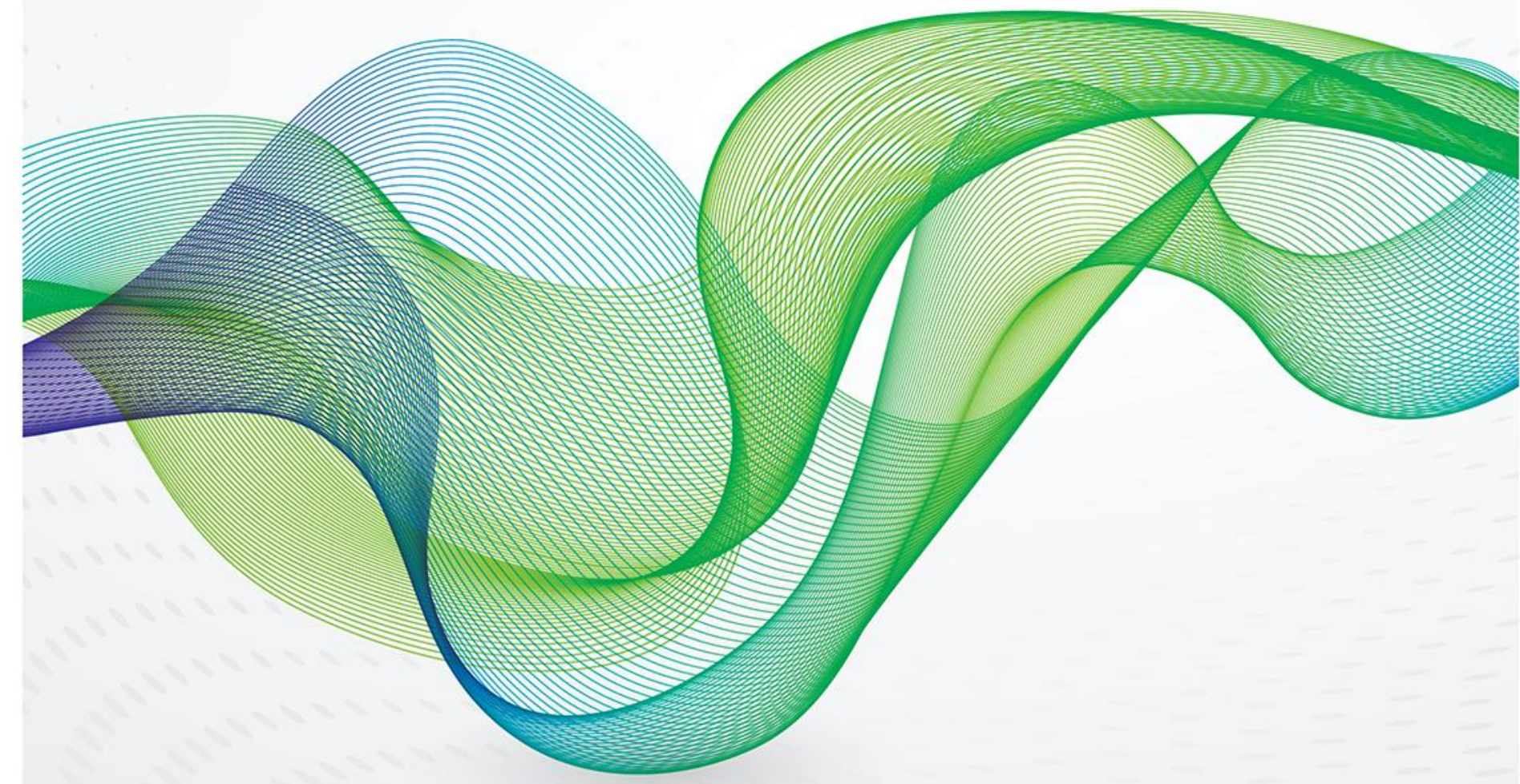



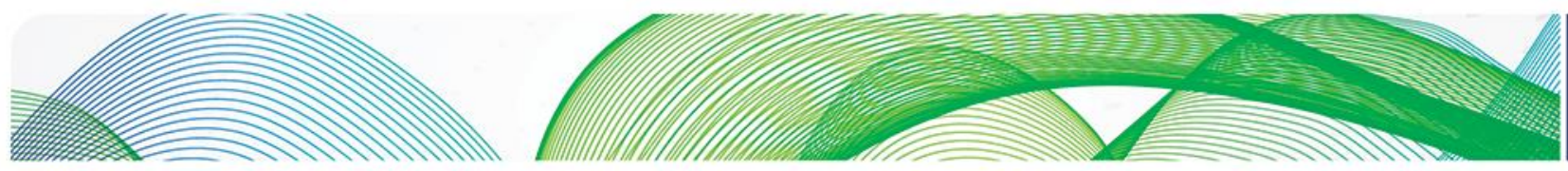

\section{잊조}

The contents of this paper are the author's sole responsibility. They do not necessarily represent the views of the Oxford Institute for Energy Studies or any of its members.

Copyright $\odot 2019$

Oxford Institute for Energy Studies

(Registered Charity, No. 286084)

This publication may be reproduced in part for educational or non-profit purposes without special permission from the copyright holder, provided acknowledgment of the source is made. No use of this publication may be made for resale or for any other commercial purpose whatsoever without prior permission in writing from the Oxford Institute for Energy Studies.

ISBN 978-1-78467-133-4

DOI: https://doi.org/10.26889/9781784671334 

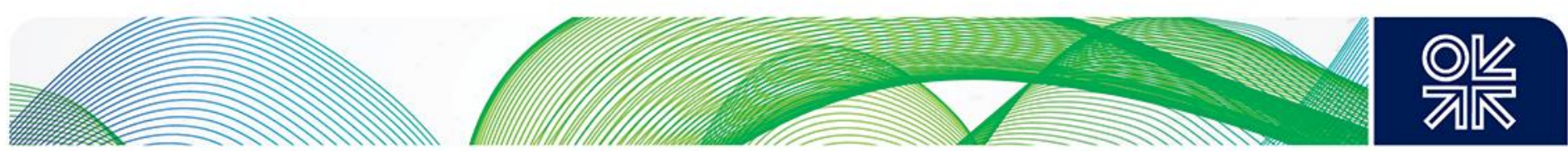

\section{Preface}

The concept of price reviews and arbitration to resolve disputes in the Asian LNG market is one which would not have merited significant analysis only a few years ago. However, these historically European phenomena, which have been used widely as the European gas market has become more competitive under new EU rules, are now becoming relevant in Asia as the global LNG market develops and the likelihood of disputes between buyers and sellers over prices and contracts across the gas world increases. As a result, this topic is becoming increasingly important and we are grateful that the author, Agnieszka Ason, has taken the time to provide an in-depth analysis of the subject. She starts by reviewing the history of price reviews in the Asian market to date, before looking at the limited role that arbitration has played so far. She then discusses why the arbitration process is likely to become more important in the Asian LNG market and looks at some of the lessons that can be learnt from Europe while also considering some of the more specific issues that will need to be faced in Asia. Finally, she looks at some of the key processes that will take place and the roles of the actors involved, before concluding that, although the transition to a greater use of arbitration in Asia is unlikely to be easy, it will be an essential part of the development of a more market-based pricing system in the region. We believe that the paper makes an important contribution to the analysis of the Asian LNG market and hope that it will be useful both for active participants in the LNG market as well as commentators and analysts of global gas market development.

James Henderson

Director, Natural Gas Programme

Oxford Institute for Energy Studies

\section{Agnieszka Ason}

Agnieszka Ason holds Polish and German law degrees and specialises in energy law and international dispute resolution. She has a particular expertise in gas pricing disputes. Having started her career at the Berlin Institute for Energy Law led by Professor Dr. Dr. Dres. h.c. Franz Jürgen Säcker, and worked on complex transactions and disputes in European and Asian natural gas markets, Agnieszka currently teaches energy law and international arbitration at the London School of Economics, Technische Universität Berlin, Freie Universität Berlin, and Queen Mary University of London. A native Polish speaker, Agnieszka is fluent in English, German, and Russian, and has a working knowledge of Ukrainian. 

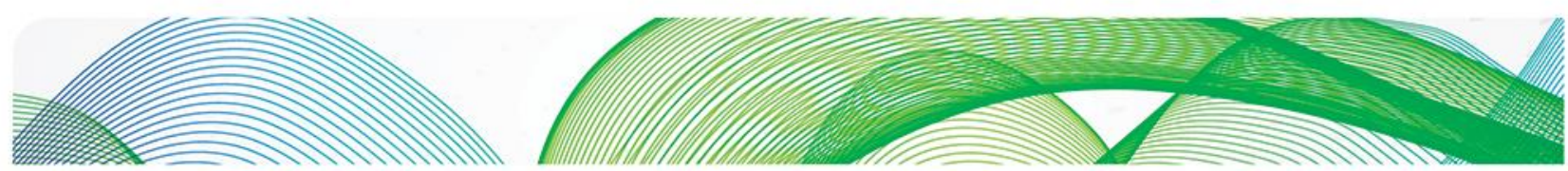

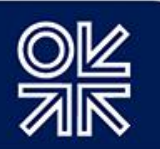

\section{Contents}

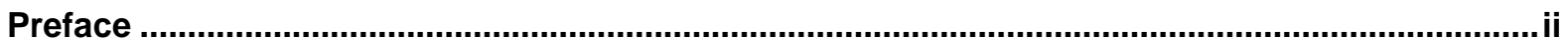

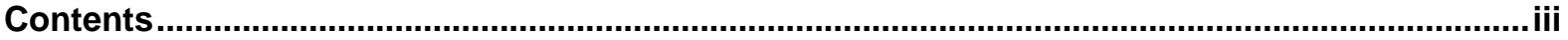

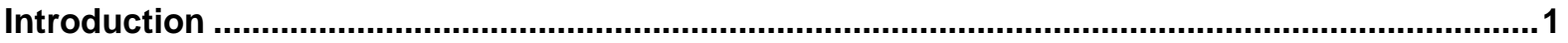

1. Asian LNG price reviews ..............................................................................................

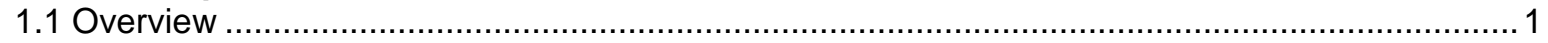

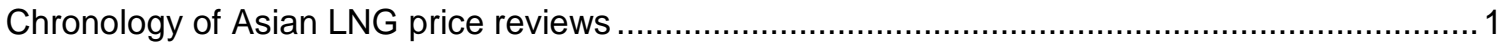

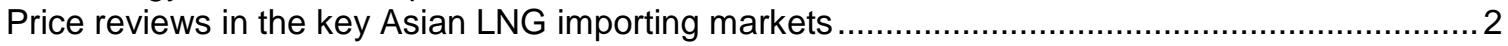

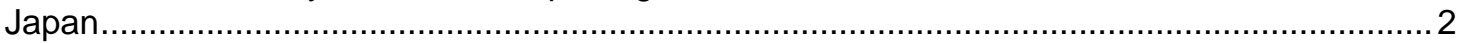

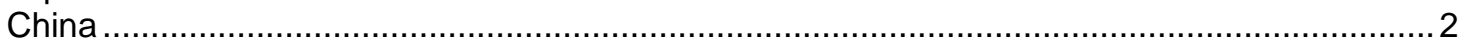

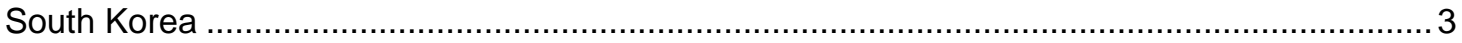

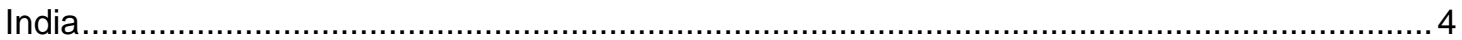

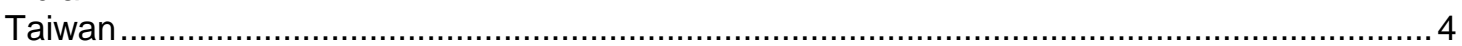

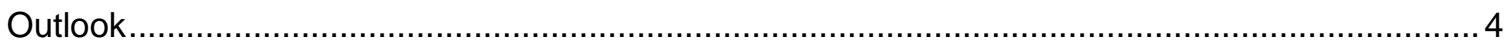

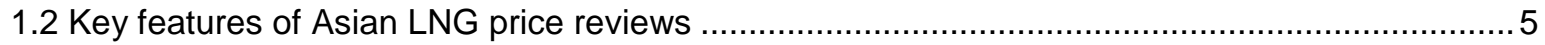

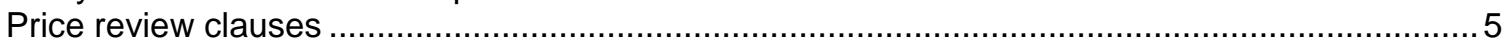

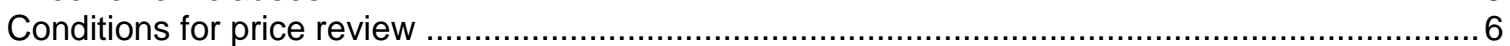

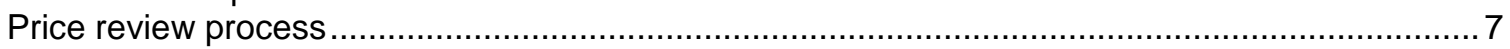

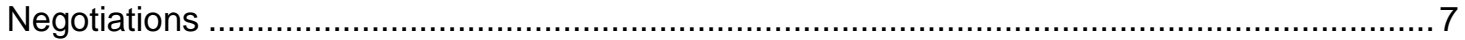

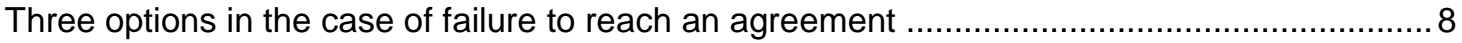

The 'fourth option' in Asian LNG contracts: uncertainty as to the next step .......................... 8

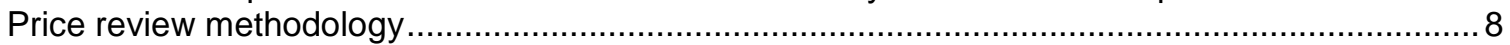

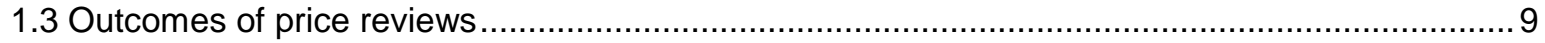

2. The role of arbitration in Asian LNG pricing disputes ..............................................................9

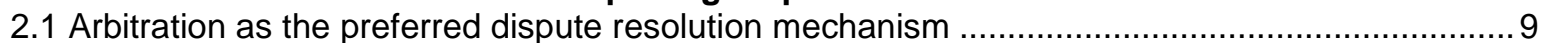

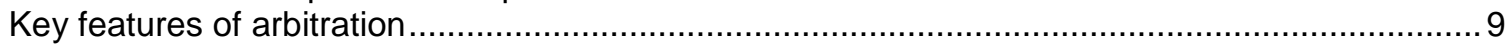

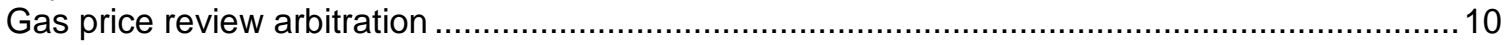

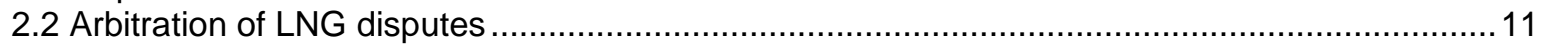

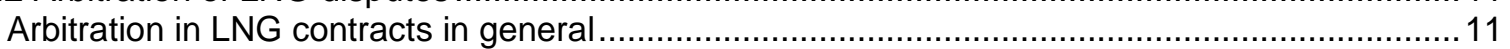

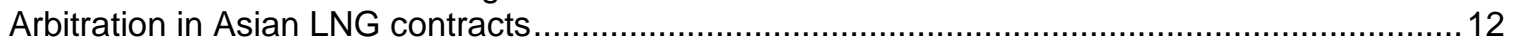

2.3 The potential for LNG price review arbitrations in Asia .................................................. 13

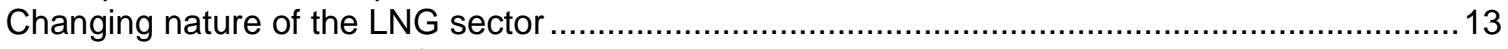

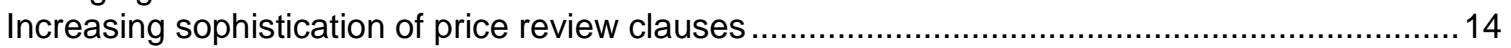

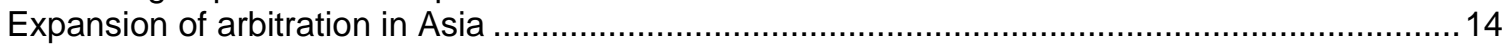

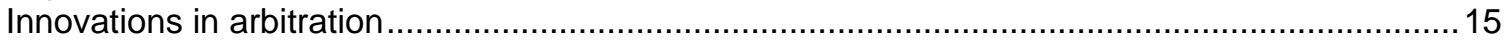

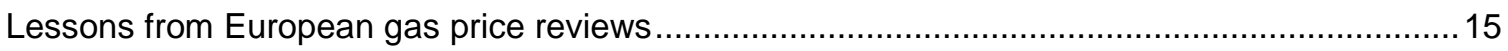

3. Key considerations in arbitration of Asian LNG pricing disputes ...........................................15

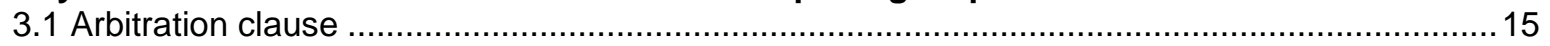

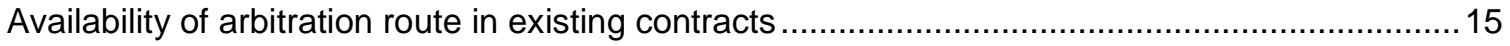

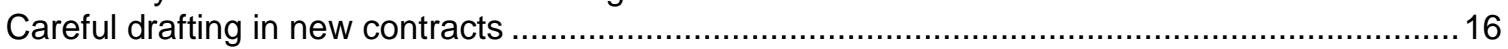

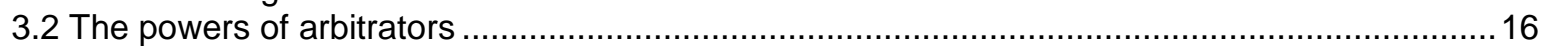

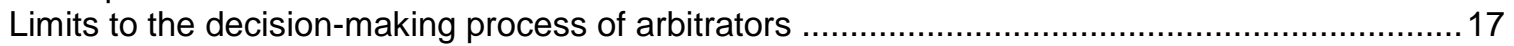

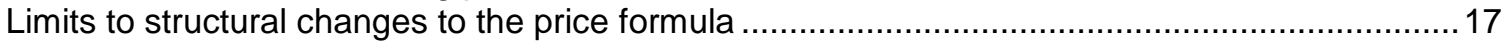

Quantitative limits to the revision of the contract price .................................................... 17

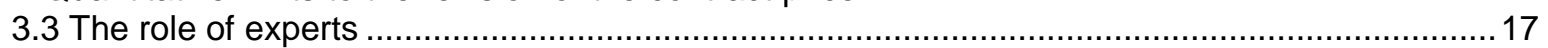

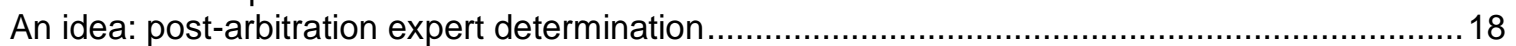

4. Summary and conclusions .....................................................................................................18

Glossary ......................................................................................................................................20

Bibliography ............................................................................................................................21 

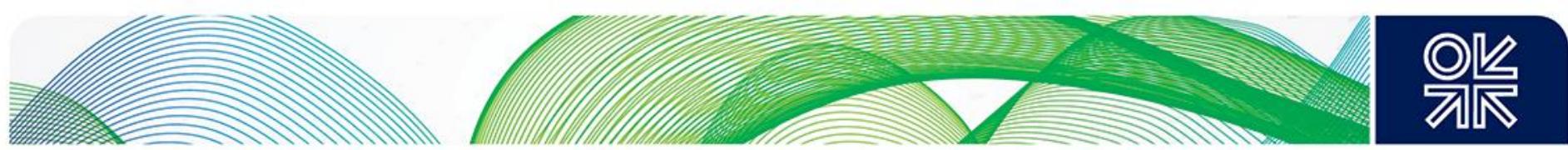

\section{Introduction}

A few years ago, the title of this paper would have been greeted with general disbelief. Until recently, Asian LNG contract issues, including price adjustments, have been resolved by negotiation, with few formal price review clauses, and certainly no price review arbitrations. These two, largely European phenomena to date, are only now spilling over into Asia. As this paper argues, the role of LNG price reviews and arbitrations in the Pacific Basin is likely to increase in the coming years. The main objective of this paper is to explore the Asian LNG price review landscape and to assess the potential of arbitration as a method of resolving pricing disputes in Asian LNG contracts. The paper is divided into four parts. Part 1 focuses on price reviews in Asian LNG importing markets and explores their scale, geographic reach, outcomes, and key features. Part 2 discusses the role of arbitration in LNG pricing disputes in Asia. Part 3 highlights some key considerations in Asian LNG pricing arbitrations. Part 4 concludes with a summary.

\section{Asian LNG price reviews}

\subsection{Overview}

\section{Chronology of Asian LNG price reviews}

The history of Asian LNG price review clauses is relatively short. In contrast to continental Europe, where long-term gas contracts 'always' included price review clauses (often referred to as 'price reopeners'), these clauses did not feature in most Asian long-term LNG contracts until the 1990s (Stern, 2016a, 488). In the absence of the most straightforward contractual basis for a price review, a party asking to reopen an oil-linked contract price for LNG had to resort to alternative options of a contractual or non-contractual nature. Other contractual provisions, including hardship clauses, could be used as a basis for renegotiation of a contract price. Industry evidence ${ }^{1}$ further suggests that some earlier contracts contained 'meet and discuss' provisions, being essentially prototypes of modern price review clauses. ${ }^{2}$ 'Outside a contract', a party determined to revise a contract price could exert commercial pressure to bring the other party to the negotiation table. ${ }^{3}$ Importantly, these alternative options were less certain than a price review process triggered on the basis of a price review clause which serves the specific purpose of adapting the contract price to market changes. ${ }^{4}$ The 'limited room for manoeuvre' (Stern, 2016b, 1) resulting from the lack of price review clauses in earlier Asian contracts naturally limited the number of price reviews pursued in Asian LNG markets.

Price reviews touch upon the most sensitive commercial interests and their details are generally shrouded in confidentiality. The Asian LNG context is no exception. The evidence of early price renegotiations, in particular, is very scarce. Industry input suggests that some buyers and sellers to Asian LNG contracts (for supplies to Japan and South Korea at that time) ${ }^{5}$ sought price revisions in

\footnotetext{
${ }^{1}$ The terms 'industry evidence', 'industry input', and 'author's research', are used interchangeably and refer to interviews with LNG industry participants conducted in preparation of this paper.

2 For example, an Asian LNG Sales and Purchase Agreement (SPA), concluded in 1960s for deliveries of Alaskan LNG to Japan, contained the following 'meet and discuss' provision: 'if in the future another [LNG] project is placed into operation to supply Japan ... under similar conditions such as volume, distance, liquefaction, and ocean transportation techniques, contract term and so forth, Sellers will hold a discussion with Buyers concerning the price ... and shall endeavor to find a solution satisfactory to all parties concerned.' The quote is taken from Weems $(2006,2)$, emphasis added.

${ }^{3}$ Commercial pressure can take a variety of forms in long-term contracts. For example, as argued by Lau (2014, 5), a party 'may be able to exert commercial pressure by referring to other existing agreements between the parties, or to future business opportunities.' Alternatively, a party may threaten to walk away from the contract if no agreement on price revision can be reached.

${ }^{4}$ For a discussion of challenges of alternative contractual avenues for a price review request see Christie and Ogut (2017).

${ }^{5}$ Japan commenced LNG imports in 1969 and South Korea in 1986.
} 

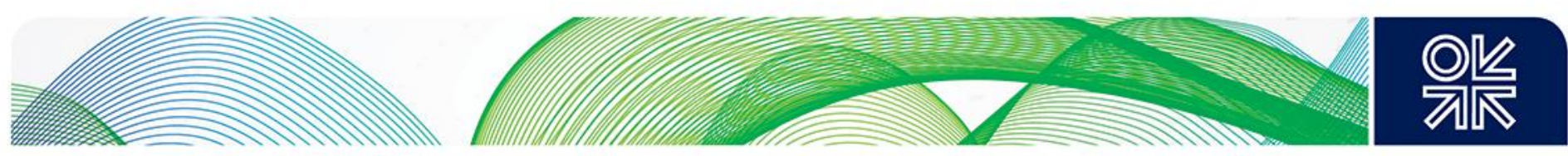

the 1970s and 1980s, depending on the level of oil prices at a given time period. In the early 1990s, gas price discussions started between Tokyo Electric Power Company (TEPCO) and Abu Dhabi Gas Liquefaction Company (ADGAS). The price in the SPA concluded by the parties in 1990 was reopened on 'several occasions', with what, in each case, resulted in lengthy negotiations between the two companies (Dargin and Flower, 2011, 460). During the buyer's market in the first years of the 2000s, when the price linked to the Japanese Crude Cocktail (JCC) exceeded the upper limit of $\$ 29 /$ bbl in Japanese contracts, ${ }^{6}$ many 'price out of range' negotiations took place (Flower and Liao, 2012,343 ), which possibly led to downward revisions of contract prices. But the first 'wave' of LNG price reviews (in relative Asian terms) ${ }^{7}$ only occurred in the period between 2010 and 2014, when several sellers requested price reviews and secured price increases. Shortly after that, in 2015, Petronet shocked the market, obtaining a roughly 50 per cent price reduction from RasGas. Since then, reports of Asian LNG buyers asking to reopen oil-linked prices in long-term LNG contracts appear regularly.

\section{Price reviews in the key Asian LNG importing markets}

Japan

Japan is the world's leading LNG importing country and, on this basis, it can be assumed that a significant share of price review discussions in the Asian LNG context involved Japanese buyers. However, public evidence of these price reviews is very limited, and rarely to be found in industry briefings or press reports. Corporate materials of Woodside Petroleum refer to 'Pluto 2014 price review' and suggest that the outcome of price review discussions over the price of supplies from the Pluto LNG project was in favour of the seller. ${ }^{8}$ In 2016, several media outlets pointed to the determination of Japanese buyers to renegotiate contractual terms in the aftermath of Petronet's success to obtain a considerable price reduction from RasGas. For example, The Economist reported at that time that JERA was planning to renegotiate contract terms with Qatar. ${ }^{9}$ In 2017, a senior official of Tokyo Gas was quoted as saying that renegotiations with various suppliers were in progress, 'including price review.'10 Industry input offers a much broader picture and suggests that Japanese buyers have triggered, or are intending to pursue, price review discussions with several sellers from LNG projects in Australia (North West Shelf, Darwin), Russia (Sakhalin), Malaysia (Tiga), and Indonesia (Tangguh, Bontang).

\section{China}

China, which recently overtook South Korea as the world's second largest LNG importer, ${ }^{11}$ started LNG imports only in the early 2000s. ${ }^{12}$ In 2001, China National Offshore Oil Corporation (CNOOC) invited the first bids for the supply of $3.3 \mathrm{mtpa}$ to the Guangdong terminal, requesting a very low slope (in comparison with the other contracts in force at that time) of 5.25 per cent, and an oil price ceiling set at $\$ 25 / \mathrm{bbl}$. The Australian North West Shelf project met the conditions requested by CNOOC and was selected as the preferred bidder. A contract, which was concluded in 2004, for deliveries for a period of 25 years did not contain a price reopener clause (Flower and Liao, 2012, 343). Industry input suggests that it was a deliberate choice to abstain from a price review clause in the first LNG

\footnotetext{
${ }^{6}$ Some Japanese contracts concluded in the 1990s, stipulated a narrow 'applicable range' of oil prices, typically between $\$ 11$ $29 /$ bbl, with the buyer and seller agreeing to meet and discuss in good faith in the event that the oil price was outside that range. See Flower and Liao (2012, 340-343).

7 For a discussion of European waves of price reviews, see Anway and von Mehren (2019).

${ }^{8}$ Woodside, 2015 Full-Year Results Briefing, Slide Pack, 17 February 2016, available at the company website, stating (at slide 33 ) that 'Pluto LNG realised pricing improved when its first price review became effective in Q2 2014.', https://files.woodside/docs/default-source/investor-documents/quarterly-and-half-yearly-pdfs-and-data-tables/2015/17-02-20162015-full-year-results-briefing-(slide-pack).pdf?sfvrsn=d1439a20 10.

${ }^{9}$ http://country.eiu.com/article.aspx?articleid=684182052\&Country=Qatar\&topic=Economy\&subtopic=Forecast\&subsubtopic=Po licy+trends\&u=1\&pid=561808840\&oid $=561808840$.

${ }^{10} \mathrm{https}: / /$ www.reuters.com/article/us-japan-Ing-tokyo-gas/japans-tokyo-gas-wants-to-revise-Ing-supply-contractsidUSKBN19Y0YH.

${ }^{11}$ https://giignl.org/sites/default/files/PUBLIC AREA/Publications/rapportannuel-2018pdf.pdf.

12 In 2006, the first shipment of LNG to China arrived at a terminal in Guangdong from Australia.
} 

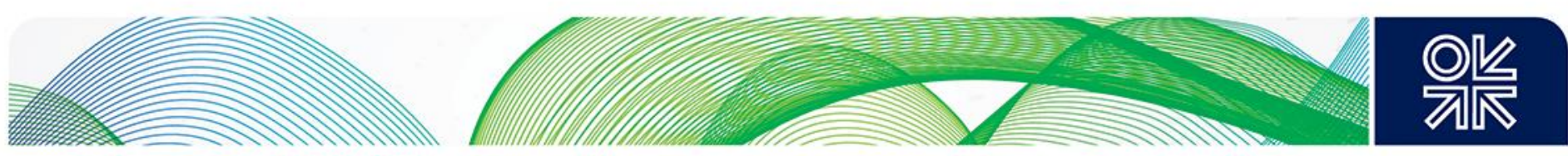

contract for deliveries to China. In 2002, CNOOC signed another 'low-price' contract for supplies from the Tangguh LNG plant in Indonesia, with the price of LNG linked to the $\mathrm{JCC}^{13}$ and capped at $\$ 25 / \mathrm{bbl}$. ${ }^{14}$ In 2006, this contract was renegotiated. The oil price cap in the amended contract (which is for 2.6 mtpa and 25 years) was raised to $\$ 38 / \mathrm{bbl} .{ }^{15}$ The first attempt by Indonesia to revise the price under the amended contract was made in $2008^{16}$ but negotiations, at that time, 'were going nowhere.' ${ }^{17}$ The 2006 contract is understood to contain a price review clause and allow for a price review every four years. ${ }^{18}$ In 2012, the Indonesian government set up a new working team for price review discussions. ${ }^{19}$ These reportedly concluded in June 2014 with an agreement which 'more than doubled the price of LNG', as compared to the price under the 2006 contract. ${ }^{20}$ In 2016, China National Petroleum Corporation (CNPC) announced that it intended to renegotiate 'the pricing method' in its long-term contract for three mtpa with Qatargas. Discussing these plans, the Chairman of CNPC suggested that the contract contained a price review clause, stating that the company was 'seeking proper time window of setting up a price renegotiation mechanism. ${ }^{21}$

\section{South Korea}

In the past, 'relatively few price reviews' took place in the Korean LNG market (Flower and Liao, 2012, 353). The exposure of Korean buyers to price review requests rose significantly in 2013 amid numerous price review requests from sellers. At that time, Petronas sought to revise the price under a 20-year contract for two mtpa of supplies from the Tiga LNG plant. Specifically, Petronas requested an upward revision of the slope to 'more than 13 per cent from less than 10 per cent.' 22 The details of the revised formula are unknown but the 'Tiga deal', which was signed as a result of price discussions, reportedly tripled the price paid by Korea Gas Corporation (KOGAS). ${ }^{23}$ In 2013, KOGAS received another price review request from Yemen LNG. Corporate materials of Yemen LNG state that the price review process concerned an SPA concluded by the parties in 2005 for the supply of 2.05 mtpa of LNG to Korea, which contained 'a Brent based price formula with floor and ceiling and a five-year renegotiation clause.' Price review discussions were triggered by Yemen LNG in June 2013 and concluded in December 2013 with a price increase. ${ }^{24}$ At that time, KOGAS was reportedly facing another price review request for deliveries from the Sakhalin project, ${ }^{25}$ and two other Korean buyers, SK Power and POSCO, were exposed to price review requests for deliveries from Tangguh. ${ }^{26}$ In POSCO's case, a 20-year contract was linked to the JCC and had an oil price ceiling, ${ }^{27}$ and reportedly contained no terms allowing for a price review. ${ }^{28}$ More recently, in February 2018, it was reported that KOGAS commenced arbitration against the North West Shelf Joint Venture (operated by Woodside Petroleum). The arbitration relates to a difference over an agreed price renegotiation during a mid-

\footnotetext{
${ }^{13}$ https://uk.reuters.com/article/indonesia-gas-china/update-1-indonesia-more-than-doubles-Ing-price-at-tangguh-for-2014idUKL4N0PC1BY20140701.

${ }^{14}$ https://www.reuters.com/article/cnooc-bp-Ing/chinas-cnooc-to-pay-more-for-bp-indonesia-gas-idUSL3N0DR2WG20130510.

15 http://topcoevents.com/topco/industry-news/industry-news/View.aspx?nid=6838.

${ }^{16} \mathrm{https://www.reuters.com/article/gas-indonesia/indonesia-to-ask-china-for-higher-tangguh-Ing-price-}$ idUSJAK21557620080314.

17 https://www.thejakartapost.com/news/2011/11/24/govt-team-review-Ing-sales-china.html.

18 https://www.spglobal.com/platts/en/market-insights/latest-news/natural-gas/010812-indonesia-to-begin-renegotiating-

tangguh-Ing-price-with-chinas-cnooc-in-jan.

${ }^{19} \mathrm{https}: / / w w w . t h e j a k a r t a p o s t . c o m / n e w s / 2014 / 07 / 01 /$ tangguh-Ing-price-raised-after-deal.html.

20 https://uk.reuters.com/article/indonesia-gas-china/update-1-indonesia-more-than-doubles-Ing-price-at-tangguh-for-2014idUKL4N0PC1BY20140701.

${ }^{21}$ https://www.forbes.com/sites/timdaiss/2016/03/11/china-national-petroleum-corp-wants-to-renegotiate-price-of-qatarigas/\#5b83b9060f8f.

22 https://www.reuters.com/article/petronas-Ing-idUSL3N0JS1W020131213.

${ }^{23}$ https://uk.reuters.com/article/uk-Ing-prices-analysis/analysis-Ing-producers-seize-upper-hand-in-global-contract-reviewsidUKBREA0K0ZV20140121.

24 http://www.yemenlng.com/ws/en/Articles/ShowArt.aspx?cmd=showone\&at=news\&artid=000178.

25 https://www.bloomberg.com/news/articles/2013-10-07/sakhalin-energy-said-to-seek-higher-Ing-price-in-korea-contract.

${ }^{26}$ https://www.thejakartapost.com/news/2014/07/02/after-china-govt-seeks-higher-gas-price-korea.html.

27 POSCO and Subsidiaries, Condensed Consolidated Interim Financial Statements (Unaudited), 30 June 2018, 62, available for download at http://www.posco.com/homepage/docs/eng6/jsp/s91a0000001i.jsp.

${ }^{28}$ https://www.thejakartapost.com/news/2014/07/02/after-china-govt-seeks-higher-gas-price-korea.html.
} 

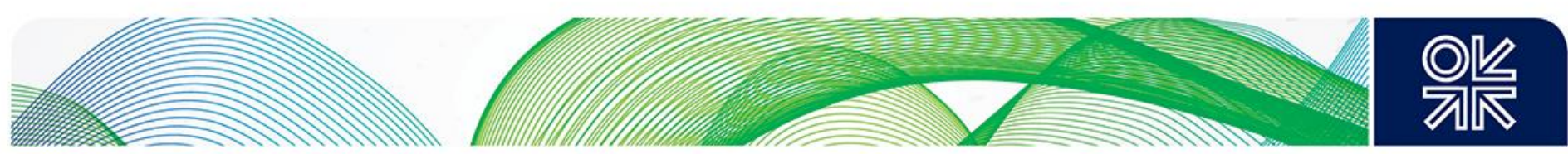

term supply contract which ended in 2016, and is widely understood to be the first-ever publicly known price review arbitration concerning an Asian LNG contract. ${ }^{29}$

India

India, the world's fourth largest LNG importing market and one of the fastest growing Asian LNG markets, has seen three publicly known LNG price reviews to date. As noted above, in 2015, Petronet secured a price reduction of around 50 per cent from RasGas. Specifically, price renegotiations concerned a 25 -year contract for $7.5 \mathrm{mtpa}$ of LNG. They reportedly commenced after Petronet lifted only 68 per cent of the contracted annual amount of LNG, ${ }^{30}$ and ultimately changed the price indexation from JCC to Brent, and added a fixed component ('constant') to the price formula. ${ }^{31}$ It is understood that, as part of the deal, RasGas agreed to waive the $\$ 1$ billion penalty under the take-orpay clause, ${ }^{32}$ and that the contract between Petronet and RasGas 'did not even allow for a price review' (Van Geuns, 2016, 2). The second such renegotiation for Petronet was the 20-year agreement with ExxonMobil for $1.44 \mathrm{mtpa}$. In 2017, the parties reportedly agreed to reduce the cost of LNG from the Gorgon project, changing the price formula from 14.5 per cent of the JCC to 13.9 per cent of Brent. ${ }^{33}$ In 2018, GAIL renegotiated with Gazprom the terms of a 20-year deal to import 2.5 mtpa, securing a reduction of the contract price. Price indexation was reportedly changed from a nine month JCC to a three month Brent linkage, ${ }^{34}$ and the slope lowered. ${ }^{35}$

\section{Taiwan}

Taiwan commenced LNG imports in 1991, and has seen 'relatively few price reviews' to date (Flower and Liao, 2012, 353). In particular, there is no evidence of recent LNG price reviews involving buyers from Taiwan which, according to the government's website, currently has four long-term LNG import contracts with Qatar, Malaysia, Indonesia and Papua New Guinea, all of which are linked to the JCC or Indonesian Crude Price (ICP). ${ }^{36}$

\section{Outlook}

Structural changes in Asian LNG markets, including a gradual move towards liberalization as well as global changes to the LNG trade reflected in an increasing flexibility of contracts, and availability of uncontracted cargos, speak in favour of a growing role of price reviews in Asia. ${ }^{37}$ Under current market conditions, and in the immediate future, buyers are most likely to request price reviews, especially if the gap between Asian spot and long-term LNG prices widens, and oil-linked contracts become untenable. Contracts concluded in the 2000s, which accepted 'ever-closer indexation of LNG to crude oil prices' (Stern, 2016b, 1) are most likely to become subject to price reviews in the coming years.

Importantly, as evidenced by the example of successful price reductions secured by Indian buyers, price reviews are not the preserve of the 'Old Asia'. Rather, buyers in the emerging LNG markets with the strongest long-term prospects for LNG growth are likely to be in the strongest position in future price renegotiations. Some signs of prospective price reviews come from Pakistan, which started LNG

\footnotetext{
${ }^{29}$ https://www.Ingworldnews.com/report-kogas-in-arbitration-with-australias-north-west-shelf-Ing-project/; https://globalarbitrationreview.com/article/1159042/korean-buyer-brings-gas-pricing-claim-against-australian-supplier. ${ }^{30} \mathrm{https}$ ://www. financialexpress.com/economy/qatars-rasgas-to-waive-1-bn-penalty-on-petronet-Ing-Itd-for-lower-gasofftake/169431/.

${ }^{31}$ https://economictimes.indiatimes.com/industry/energy/oil-gas/qatar-scraps-floor-cap-in-gas-price-formula-withindia/articleshow/50424196.cms.

32 Petronet agreed to buy the quantities it did not take in 2015 during the remainder of the contract period. ${ }^{33}$ https://www.bloomberg.com/news/articles/2017-09-11/india-swaps-cheaper-Ing-for-higher-volumes-in-2nd-reworked-deal. 34 https://tass.ru/tek/4880710.

${ }^{35}$ http://timesofindia.indiatimes.com/articleshow/64450442.cms?utm source=contentofinterest\&utm medium=text\&utm campai gn=cppst.

${ }^{36}$ https://www.moeaboe.gov.tw/ECW/english/content/Content.aspx?menu id=1693.

37 See Trimble $(2018,437)$, who argues that, in the future, 'Far East LNG buyers will be buying on a very different basis from the past' and further notes that there 'will probably be a greater use of shorter term contracts and spot cargo purchases and the buyers may increasingly trade surplus volumes rather than just being solely a purchaser of LNG.'
} 

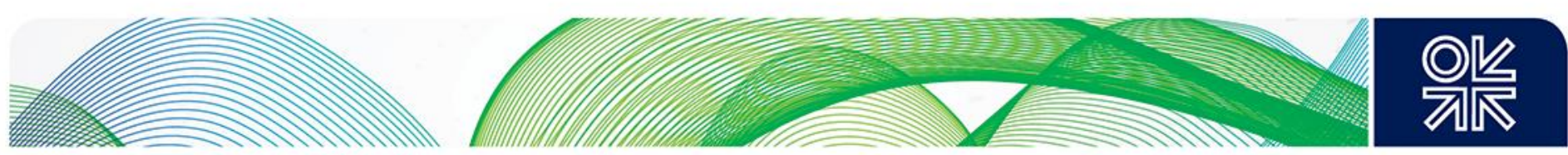

imports only in 2015, and, since then, has seen an 'ongoing acceleration in LNG imports' (Arif, 2017, 4). In October 2018, the Competition Commission of Pakistan advised domestic LNG importers to renegotiate their existing long-term contracts (and to revise their LNG supply negotiation strategies going forward). In particular, the competition authority warned the buyers against oil price indexation and 'invited' them to consider 'alternative pricing indexations like NBP, Henry Hub and JKM.' 38 Pakistan has currently oil-linked supply contracts for more than $10 \mathrm{mtpa}$ with Qatargas, Eni, Shell, and Gunvor. The largest volume contract with Qatargas for $3.75 \mathrm{mtpa}$, which is linked to Brent (with the slope set at 13.37 per cent, and no oil price ceiling), ${ }^{39}$ is reportedly already subject to price review discussions, which started in January 2019 with a meeting of high-level state officials from both countries in Qatar. ${ }^{40}$ Looking further into the 'New Asia', Thailand, another rapidly growing LNG market, (which is reportedly committed to booking as much as 70 per cent of its LNG imports on longterm contracts with the remaining 30 per cent coming from the spot market),$^{41}$ as well other emerging LNG markets which base their import strategy on long-term contracts, are also likely to see LNG price reviews in the future.

\subsection{Key features of Asian LNG price reviews}

\section{Price review clauses}

To recall, a price review clause offers parties to an SPA the most straightforward option to request a revision of the contract price. In European contracts, a price review clause is likely to point to a 'significant change of economic circumstances' in a particular market (being most commonly the buyer's market), ${ }^{42}$ and reads along the following lines:

If the economic circumstances in the country of the Buyer, which are beyond the control of the Parties, should change significantly compared to what is reflected in the prevailing price provisions ..., then each Party shall be entitled to an adjustment of the price provisions ..., reflecting such changes, in particular the value of Natural Gas in the end user market of the buyer as such value can be obtained by a prudent and efficient gas company... ${ }^{43}$

Asian LNG contracts finalized in recent years typically contain price review clauses (Stern, 2016a, 488). However, as evidenced by CNOOC's contract for supplies from the North West Shelf, even the newer contracts may lack price reopeners. At the same time, it is not uncommon to see price review clauses containing major omissions, contradictions, or other drafting flaws, which render them invalid or unworkable. In short, the availability of an enforceable price review clause in an Asian LNG contract is far from self-evident.

Contractual provisions providing for price reviews are typically strictly confidential and there are no publicly available arbitral awards or court judgments concerning Asian LNG contracts which could offer knowledge of their contents. There is, however, one relevant example of an Asian LNG price review clause in the public domain which (rather unusually) can be read directly from a contract. This example is set out in a recent long-term SPA between Qatargas and Pakistan State Oil Company

\footnotetext{
38 https://www.spglobal.com/platts/en/market-insights/latest-news/natural-gas/112218-analysis-pakistan-warns-Ing-importersagainst-oil-linked-contracts.

${ }^{39}$ https://nation.com.pk/16-Jan-2019/renegotiating-the-qatar-deal.

40 http://interfaxenergy.com/gasdaily/article/33872/pakistan-seeks-lower-cost-Ing-from-gatar.

41 https://www.Ingworldnews.com/thailand-to-focus-on-securing-long-term-Ing-supply-deals/.

42 'Troll contracts' (that is, contracts for deliveries of gas from Troll gas field in Norway), in particular, refer to the buyer's market. Some other contracts take a wider market (regional or international) as a reference market. For example, an arbitral tribunal in ICC (International Chamber of Commerce) Case No. 15051 found that "the [contract] did not follow the "Troll philosophy" and thus did not exclusively focus on the purchaser market, but on elements of the international energy market.' (emphasis added). ${ }^{43}$ Excerpt from a price review clause in ICC Case No. 9812.
} 

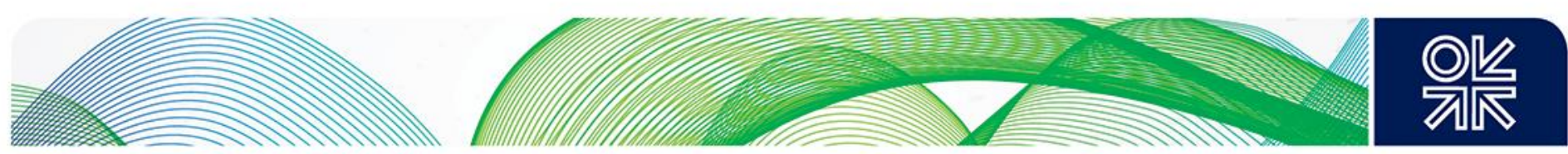

(PSO) which is freely accessible on the PSO's website. ${ }^{44}$ The price review clause in that contract reads as follows:

\subsection{Contract Price Review}

15.2.1 A Party may give a notice ("Price Review Notice") to the other Party to renegotiate the Contract Price no earlier than [redacted].

15.2.2 Following the issue of the Price Review Notice, the Parties shall meet in good faith and discuss the matter with a view to agreeing what Price Adjustment (if any) is required.

15.2.3 If the Parties agree upon such matters, they shall amend the Contract Price to reflect the revisions (if any) so agreed. Such revised Contract Price shall apply from the Review Date pursuant to Clause 15.2.5 until the end of the Supply Period and neither Party is entitled to give a further Price Review Notice to the other Party.

\subsection{4 [redacted]}

15.2.5 Any Price Adjustment which is agreed by the Parties shall take effect in respect of all deliveries of LNG under this Agreement for which the Completion of Unloading falls on or after the date of the Price Review Notice (the "Review Date"). Until any such Price Adjustment has been agreed, the Contract Price shall be determined on a provisional basis under the formula prevailing prior to the Price Adjustment (...).

15.2.6 This Agreement and, in particular, the rights and obligations of the Parties, including, without limitation, the obligations of the Seller to sell and deliver and the obligations of the Buyer to take and/or pay for LNG at the Contract Price, shall remain in full force notwithstanding that the Parties have not reached agreement on a Price Adjustment, unless and until terminated in accordance with Clause 15.2.4 or Clause 24.

This example of a price review clause will be frequently referred to in the discussion below.

\section{Conditions for price review}

Price reviews in long-term Asian LNG contracts can be typically triggered after a set number of years from the date of first delivery, and at regular intervals thereafter (Flower and Liao, 2012, 353). Industry evidence suggests that most Asian LNG contracts from the 1990s provided for a price revision at intervals in the range of five to ten years. Modern contracts tend to stipulate shorter price review periods, typically of four or five years. This, potentially, signals the gradual movement towards narrower price review intervals as seen in European contracts. ${ }^{45}$ Nonetheless, price review clauses in Asian LNG contracts still very rarely stipulate that the price review can be requested outside the regular price review periods, or 'at any time', subject to the occurrence of some specified circumstances. ${ }^{46}$ The scarce availability of non-periodical reviews necessarily constrains the parties in their attempts to revise the price, essentially forcing them to await the next time window to submit their request. Moreover, some Asian LNG contracts expressly limit the number of price revisions throughout the life of the contract, in some cases, to a one-off revision of the contract price. ${ }^{47}$

Grounds for price review in Asian LNG contracts are generally very limited. Most importantly, they are unlikely to include a 'significant change in economic circumstances in the buyer's market' (as seen most commonly in European contracts). Although some Asian price review clauses refer to 'changes in economic circumstances', as such, these are either put in a broader geographic context than the buyer's market (and need to occur, for example, 'in Asia-Pacific'), or remain detached from any

\footnotetext{
${ }^{44}$ Long-term SPA between Qatar Liquefied Company Limited (2) and Pakistan State Oil Company Limited, 8 February 2016, available at https://psopk.com/files/pdf/QG-PSOredactionofSPA051016.pdf (execution copy).

${ }^{45}$ In European contracts, the most usual price review period is three years. See Stern (2016a), 489.

${ }^{46}$ Author's research.

${ }^{47}$ See Qatargas - PSO SPA, Clause 15.2.3 (stating that, if the parties agree on price adjustment, 'neither Party is entitled to give a further Price Review Notice to the other Party.').
} 

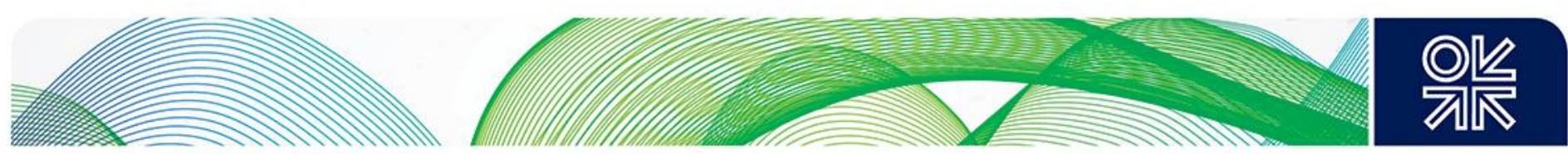

particular market. ${ }^{48}$ Rather than on buyer's market conditions, Asian price reopeners tend to focus on comparison with the current import prices, or prices in the new long-term LNG contracts concluded in a specific geographic region (Davis, 2014, 32).

Other types of triggers for price reviews are, of course, feasible in Asian LNG contracts but it has been suggested that purchasers in key LNG importing markets are at present likely to be limited in their options to demand price reviews unless a demonstration can be made that the pricing is unreasonably high in comparison to other suppliers or contracts. ${ }^{49}$

Upon first impression, the general lack of reference to buyer's market conditions in price review clauses in Asian LNG contracts seems striking. However, specifically in the Asian LNG context, it is unsurprising, and clearly derives from the historical capability of Asian buyers (not infrequently state monopolies) to pass through price increases to their customers. This is likely to change in the future, especially considering that liberalization of Asian LNG markets will inevitably mean that the buyers will operate in a more competitive environment restraining their ability to pass through the costs of LNG and maintain profitability at the expense of end-users. Asian buyers can, therefore, be expected to build protection against price increases into renegotiated or newly drafted price review clauses. Accordingly, downstream market conditions are likely to become more relevant in future LNG price reviews in Asia.

\section{Price review process}

\section{Negotiations}

Negotiations, in the Asian context often referred to as 'good faith discussions', are typically the first step in the price review process. The contractual basis for good faith discussions is likely to read in an Asian LNG contract along the following lines:

... if Seller or Buyer desires a review of the prices set out in this Agreement due to a change in relevant circumstances resulting in such prices being significantly disadvantageous to either Seller or Buyer compared with the prices for other LNG sold into Japan on similar terms to this Agreement, then ... Buyer and Seller shall meet and discuss in good faith to review such prices. ${ }^{50}$

Typically, gas price review negotiations are subject to a specific deadline (for example, 120 days in some European contracts). However, this is not always the case with Asian contracts, which sometimes do not stipulate any negotiation period. ${ }^{51}$ The length of negotiations can therefore prove uncertain. Most good faith discussions involving Asian stakeholders have been protracted and some took many years to resolve, as exemplified by the anecdotal evidence of the 'price out of range' discussions with Japanese buyers triggered in the early 2000s which had not been concluded 'by the time the buyer's market gave way to the seller's market' (Flower and Liao, 2012, 343). Contemporary gas pricing discussions in Asia remain widely perceived as lengthy, especially if compared to timelines experienced in European gas price reviews.

Negotiations are typically purely commercial in nature and limited to the parties to the contract. However, specifically in Asia, they can be expected to touch upon sensitive political interests and involve external actors, including government officials. For example, price discussions concerning the Tangguh LNG project (which were announced by the Indonesian President on Twitter ${ }^{52}$ reportedly included delegates from the Indonesian energy regulator and energy and finance ministries. ${ }^{53}$ The involvement of governments in price renegotiations can take a variety of forms. Although there is no

\footnotetext{
${ }^{48}$ Author's research.

${ }^{49}$ Oghigian, Henneberry, and Jones $(2017,4)$.

${ }^{50}$ Example from Paul Griffin, quoted in Leggatt $(2018,4)$, emphasis added. See also, Qatargas - PSO SPA, Clause 15.2.2.

${ }^{51}$ As exemplified by the price review clause in the Qatargas - PSO SPA.

52 In 2013, the Indonesian President Susilo Bambang Yudhoyono tweeted (in Indonesian): 'China's leaders have agreed over

my proposal to renegotiate Tangguh price in a bid to allow Indonesia to get higher value.'

${ }^{53}$ http://topcoevents.com/topco/industry-news/industry-news/View.aspx?nid=6838.
} 

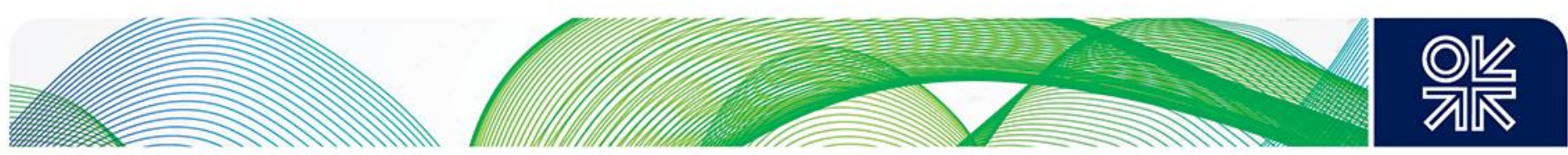

evidence that Asian LNG contracts would require the outcome of a price review to be formally approved by governmental authorities, this requirement can be present in national laws, ${ }^{54}$ or be reflected in the practical need to obtain a blessing from one or two governments. All these factors can potentially lead to additional delays in the price review process.

Three options in the case of failure to reach an agreement

In general, if the parties fail to reach an agreement within the negotiation period, a price review clause will provide for one of three options: (i) the contract will continue unchanged; (ii) either party will have the right to terminate the contract; and (iii) the dispute will be referred to an external party (Griffin and van Eupen, 2014, 148). The availability of these options in Asian LNG contracts is briefly discussed in turn below.

First, some Asian LNG contracts make it clear that if no agreement is reached, the contract 'shall remain in full force' notwithstanding that the parties failed to agree on price adjustment. ${ }^{55}$ This essentially means that the gas supply contract will continue to operate unamended even if the parties remain misaligned as to the contract price.

Second, some Asian LNG contracts offer both parties the right to terminate the contract if they are unable to agree on price adjustment. For example, the SPA between Qatargas and PSO provides that the 'Agreement ... shall remain in full force notwithstanding that the Parties have not reached agreement on a Price Adjustment, unless and until terminated in accordance with Clause 15.2.4....56 The termination provision in question, forming an integral part of the price review clause, has been redacted, and remains confidential. On the basis of comparison with other contracts, it is likely to offer the right of termination to either party, upon giving notice to the other party, in the case of the failure of the parties to reach an agreement on price adjustment within a specified period of time. Clearly, the option of contract termination is a rare feature of Asian LNG price review clauses which, as industry input suggests, is likely to be limited to the most recent contracts.

The third alternative in the event of the parties' failure to reach an agreement in negotiations is the right of either party to submit the dispute to an external dispute settlement mechanism. This will be the case with most European contracts which, as discussed below, routinely refer the parties to arbitration. Asian LNG contracts do not follow the European pattern of a strong preference for arbitration. Strikingly, as industry input suggests, many of them do not refer the parties to any thirdparty dispute settlement mechanism.

\section{The 'fourth option' in Asian LNG contracts: uncertainty as to the next step}

Instead of providing for any of the three standard alternatives, some Asian LNG contracts take a distinct approach and remain silent on the issue of available options in the event of failed price negotiations. As suggested by Davis $(2014,32)$, the question of the next steps can prove to be such a sensitive matter in contract negotiations in Asia that parties, 'consciously or unconsciously', leave it open. This solution, essentially exposing the parties to uncertainty as to the next step in the price review process, forms a prevalent feature of the older Asian price review clauses and is not uncommon in newer agreements. ${ }^{57}$

\section{Price review methodology}

A limited number of Asian LNG contracts offer detailed guidance as to the factors which should be taken into account in price adjustment. These include a 'market parity' clause which seeks to ensure that the price will not be out of line with a particular comparator. For example, if a comparison is made against current imports to Japan, the price review clause may stipulate that the revised price 'shall be

\footnotetext{
54 This can be inferred from the need to obtain state approval for the new or renegotiated contracts in some jurisdictions.

${ }^{55}$ Author's research.

${ }^{56}$ Qatargas - PSO SPA, Clause 15.2.6 (emphasis added).

57 Author's research.
} 

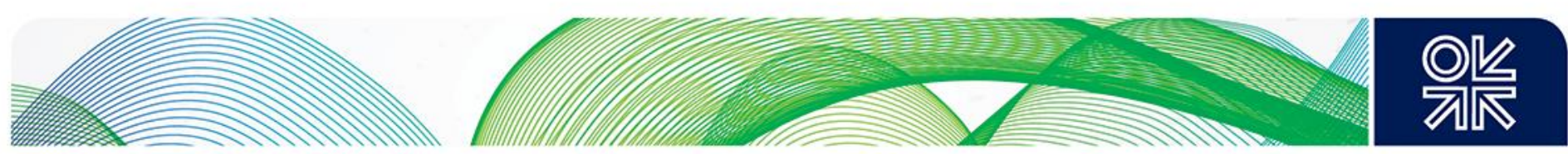

based on the pricing of similar sales into Japan' (Davis, 2014, 32). In these cases, price discussions will be informed by the need to achieve a specific result.

However, most price review clauses in Asian LNG contracts are general in nature and say very little (Stern, 2016a, 489), if anything, about the factors which should be taken into account in a price review. Industry evidence suggests that some Asian price reopeners refer to 'various factors' or broader economic considerations (like 'levels and trends in the price of oil and gas in Asia-Pacific region') which should guide price review discussions. In addition, or in the alternative, some Asian LNG contracts require that the price adjustment shall be 'appropriate', 'reasonable', 'equitable', 'fair and justified', or apply a combination of these, or similar, thresholds. Other price review clauses do not specify any instructions or expectations as to the price review and merely stipulate, for example, that the parties shall ... discuss the matter with a view to agreeing what Price Adjustment (if any) is required. 58

\subsection{Outcomes of price reviews}

Asian LNG price reviews resulted in both upward and downward price revisions, which in some cases halved or tripled the prices, and often significantly altered the original pricing arrangement. However, reported price reviews have not involved wholesale structural changes to pricing mechanisms. In particular, there is no evidence of any Asian LNG contract price review, which would result in the departure (even partial) from oil indexation. ${ }^{59}$ Rather, LNG Asian price reviews were limited to more or less extensive changes to specific components of a given oil-linked formula. Changes to the slope were at the heart of most price revisions involving Asian stakeholders, especially in the 2013-2014 wave of price reviews which led to several upward slope adjustments. In comparison, revisions of the constant were less frequent, but are not uncommon. In addition, or in the alternative, some price reviews resulted in changes to oil price floors/caps, or oil indices (mainly abandoning the link to JCC in favour of Brent).

Notably, all reported outcomes of Asian LNG price reviews were achieved in negotiations, which, in the language of European price revisions, could be described as 'at the pre-arbitration stage.' In the Asian context, the narrative has been different, and the claim filed by KOGAS remains the only publicly known example of an Asian gas price review arbitration to date. There is, however, some expectation that 'others may follow' 60 , or that Asia will become 'the next major battleground' in gas price review arbitration (Anway and von Mehren, 2019, 207).

\section{The role of arbitration in Asian LNG pricing disputes}

\subsection{Arbitration as the preferred dispute resolution mechanism}

\section{Key features of arbitration}

Arbitration is the preferred dispute resolution mechanism in international commercial contracts. ${ }^{61} \mathrm{As}$ an alternative to litigation before national courts, arbitration offers parties remarkable flexibility, which is reflected in a variety of procedural choices. In particular, the parties can choose the decision makers acting as private judges ('arbitrators'), a neutral place ('seat') of arbitration, the most suitable arbitral rules, the involvement of the administering institution, and the language of arbitration. Furthermore, the parties can determine many other aspects of arbitration, including the desired timeframe, structure, and level of confidentiality of arbitral proceedings. In essence, the users of arbitration can tailor the arbitral process to their needs.

\footnotetext{
${ }^{58}$ Clause 15.2.2 of the Qatargas - PSO SPA (emphasis added).

${ }^{59}$ Although some Asian LNG contracts use hybrid pricing or gas price indexation, these alternative formulae were introduced to newly signed or amended contracts, and not as a result of price reviews triggered on the basis of existing contracts. ${ }^{60} \mathrm{https}$ ://www.reuters.com/article/us-asia-Ing-arbitration/as-kogas-goes-into-Ing-arbitration-others-may-followidUSKBN1FX0MK

${ }^{61}$ Anecdotal evidence suggests that 90 per cent of international commercial contracts contain an arbitration clause.
} 

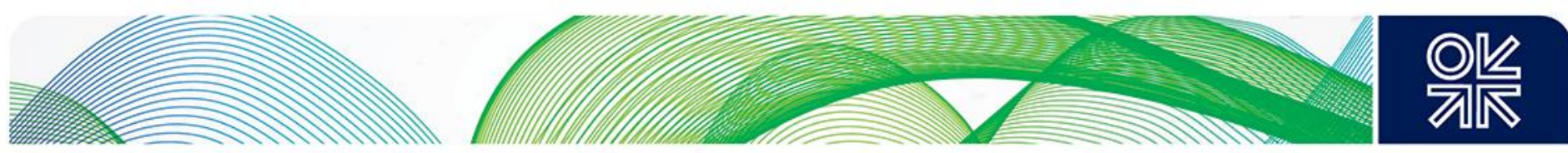

The outcome of arbitration ('arbitral award') cannot be disregarded by the losing party. It is binding and can be enforced across the globe in all countries which have ratified the New York Convention on the Recognition and Enforcement of Foreign Arbitral Awards. ${ }^{62}$ The options of recourse against an arbitral award are very limited, and typically do not include an appeal. In most jurisdictions, an unfavourable award can be challenged before national courts on narrowly defined grounds. In the absence of violations of due process or mandatory rules pertaining to public policy (for example, competition laws), the prospects of a successful challenge are very low. In the vast majority of cases, arbitral awards are final and voluntarily complied with.

\section{Gas price review arbitration}

Arbitration is the preferred method for resolving gas pricing disputes in European contracts. Especially post-2008, European price review arbitrations expanded and become 'relatively common events in relation to both pipeline and LNG contracts' (Stern, 2016a, 489).

Parties to gas supply agreements favour arbitration for pricing disputes due to its flexibility, the full privacy of the process and confidentiality of the outcome, which they typically request, considering the sensitive nature of pricing arrangements and market information in gas price reviews. As complex and high-stakes disputes, gas price review arbitrations are typically heard by three arbitrators (forming an 'arbitral tribunal'), rather than by a sole arbitrator. There are several different methods of appointing an arbitral tribunal but the parties typically choose arbitrators on their own on the basis of careful due diligence of the prior experience of a particular candidate. The two party-appointed arbitrators then choose the third arbitrator ('chair') who presides over the arbitration. In the alternative, the parties sometimes seek assistance of an arbitral institution which will act as an appointing authority. The role of an arbitral institution in arbitral proceedings depends on the preferences of the parties. Some wish to have their proceedings administered by a particular institution, for example, London Court of International Arbitration (LCIA). Others opt for ad hoc arbitration, which they conduct on their own, typically in accordance with Arbitration Rules of the United Nations Commission on International Trade Law (UNCITRAL), which are suited for non-institutional proceedings.

European price review arbitrations to date have been both institutional and $a d$ hoc, and conducted under various arbitral rules, including the UNCITRAL Rules, LCIA Rules, ICC Rules, or the Rules of the Arbitration Institute of the Stockholm Chamber of Commerce (SCC). They were seated in different locations, including Stockholm, London, Geneva, and Paris. The following arbitration clause, set out in the gas supply contract between Naftogaz and Gazprom, is reflective of some choices which can be made in a gas price review arbitration:

...The Parties shall seek to resolve between themselves all disputes and controversies relating to the interpretation and application of this Contract by means of negotiations. Should the Parties fail to reach a mutually acceptable solution within 30 days upon the occurrence of any dispute or controversy, any dispute, controversy or claim in connection with the present Contract either its breach, termination or invalidity shall be finally resolved by arbitration in accordance with the Rules of the Arbitration Institute of the Stockholm Chamber of Commerce. The Arbitral Tribunal shall consist of three Arbitrators. The Arbitration shall be held in Stockholm, Sweden. The language of the arbitration proceedings shall be Russian. The arbitral award shall be final and binding on both Parties...63

\footnotetext{
62 As of March 2019, 159 states are Contracting Parties to the New York Convention.

${ }^{63}$ Contract between Naftogaz of Ukraine and Gazprom no. KP for the purchase and sale of natural gas for the period 20092019, 19 January 2009. Excerpt from the arbitration clause set out at Article 8, as reproduced by the tribunal in SCC arbitration no. V2014/078/080, Final Award, 22 December 2017, at para. 5, which is available at http://www.naftogaz.com/files/media/Final\%20Award\%20Redacted.pdf (emphasis added)
} 

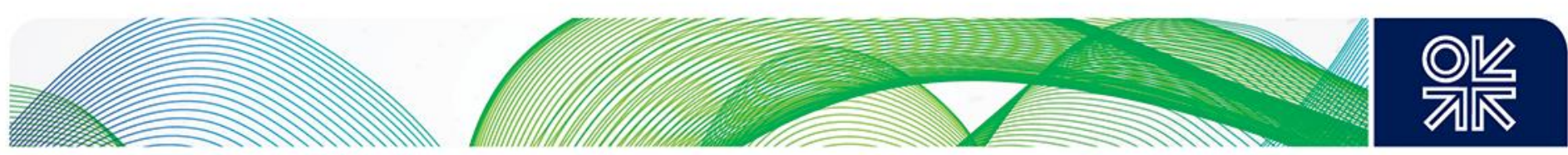

Arbitration can be either the only method of dispute resolution in a contract, or be preceded by a prearbitration step, for example, negotiations. The latter option is most common in European gas supply contracts and allows the parties to first explore the informal negotiation route before submitting the dispute to arbitration. Theoretically, the choice of the parties is not limited to these two tiers, and the arbitration clause could provide for more steps in the dispute resolution process. For example, as suggested by Griffin and van Eupen $(2014,154)$, mediation could be inserted as an extra step between negotiations and arbitration, which could offer additional encouragement to the parties to reach agreement without the need to resort to adversarial proceedings. At the same time, it is unlikely that any less adversarial proceedings than arbitration, like mediation, conciliation, or expert determination, could be successfully applied as a full alternative to arbitration. Mediation and conciliation both require involvement of a third-party (mediator/conciliator) but, unlike arbitration and expert determination, do not produce a final and binding outcome. Expert determination is a closer alternative to arbitration, but is widely seen as a less compelling option for reasons including that parties may not be comfortable leaving a decision on the gas price review to an expert 'without any legal background.' 64

\subsection{Arbitration of LNG disputes}

\section{Arbitration in LNG contracts in general}

The advantages of arbitration were recognized early by the LNG industry. In the 1960s, arbitration, rather than litigation, 'was already the norm' in LNG contracts (Weems, 2006, 1). For example, the LNG SPA between Distrigas and Sonatrach concluded in 1976 contained the following arbitration clause:

Any dispute between the parties hereto relating to the construction or the performance of the terms of this agreement shall be settled by arbitration in Geneva, Switzerland, [under] the rules of conciliation and arbitration of the International Chamber of Commerce by one or more arbitrators appointed in accordance with such rules. The arbitration award shall be final and without any appeal being open. The parties shall perform the arbitration award without any exception or reservation. $(. . .)^{65}$

Over the past fifty years of LNG trade, contracts systematically included arbitration clauses. ${ }^{66}$ In recent years, the LNG industry has become 'increasingly litigious' and that 'shows no sign of receding' (Baily and Lidgate, 2017, 320). Disputes submitted to arbitration covered a broad range of issues including pricing, supply failures, construction delays, tariffs, storage, shipping, and claims brought by investors against states. ${ }^{67}$ To date, the majority of disputes are related to the determination of the price of LNG in long-term contracts (Bohmer, 2015, 486).

Only a few LNG price review arbitrations are in the public domain. The best known example is the Atlantic LNG arbitration which was confidential but became publicly known in 2008 through postarbitration judicial proceedings before a US court. ${ }^{68}$ The arbitration concerned a price review triggered by Atlantic LNG on the basis of a 20-year gas supply agreement between Atlantic LNG and Gas Natural, and was seated in New York and conducted under UNCITRAL Rules. The case is discussed in detail by Griffin $(2017,114-116)$. More recently, Edison prevailed in an arbitration conducted under ICC Rules against RasGas in relation to a price review under a 25-year SPA executed between the

\footnotetext{
64 Terceño, Phua, and Stennett, 2018, 13

${ }^{65}$ Agreement for the Sale and Purchase of Natural Gas between Sonatrach and Distrigas Corporation, 13 April 1976, available at http://www.secinfo.com/dsvRx.bmw.a.htm\#1stPage, emphasis added.

${ }_{66}^{6}$ For an overview of contractual practice over the last decades see Weems (2006).

${ }^{67}$ For the most recent example of an investment treaty arbitration concerning the LNG sector, see Unión Fenosa Gas, S.A. $v$ Arab Republic of Egypt, ICSID Case No. ARB/14/4, Award, 31 August 2018. https://www.italaw.com/sites/default/files/casedocuments/italaw10061.pdf.

${ }^{68}$ Gas Natural Aprovisionamientos v Atlantic LNG Co. of Trinidad Tobago (2008) WL 4344525 (SDNY 2008).
} 

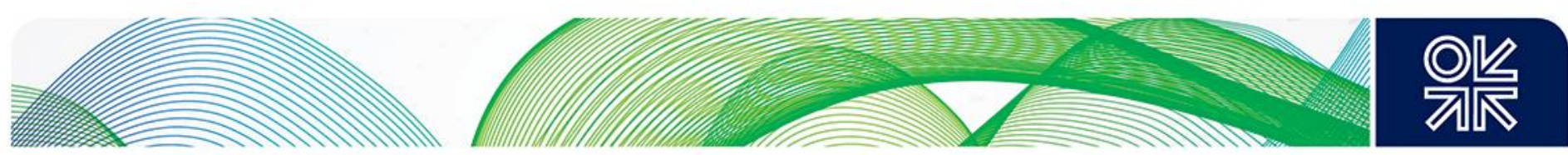

two companies. ${ }^{69}$ Other recent examples include LNG price review arbitrations between Edison and Sonatrach, Edison and Eni, RasGas and Distrigas, and RasGas and Endesa. ${ }^{70}$

\section{Arbitration in Asian LNG contracts}

Although pricing disputes have traditionally dominated the global LNG disputes portfolio, and European price review arbitrations have been initiated 'since the early years of the trade' (Stern and Koyama, 2016, 37), this has not been the case in the Pacific basin. At the same time, industry evidence strongly suggests that Asian LNG contracts routinely provided for arbitration and that, in practice, Asian buyers and sellers used arbitration for a variety of non-pricing, mainly infrastructurerelated, disputes in both domestic and international settings. Notably, the first Asian LNG SPA, which was signed in 1967 for the sale of LNG produced by Phillips and Marathon Oil in Alaska to Tokyo Electric and Tokyo Gas, stipulated that any disputes will be resolved by 'arbitration in Tokyo with the arbitrators applying Japanese law. ${ }^{71}$ Clearly, there is no general reluctance in the Asian LNG industry to using arbitration, or any particular preference for another third-party dispute resolution mechanism (like litigation), what could explain the low use of arbitration for Asian LNG pricing disputes. ${ }^{72}$ As evidenced by the European experience, pricing disputes, as contractual disputes, are well suited for arbitration..$^{73}$ Nevertheless, for some reason, parties to Asian LNG contracts have remained largely unresponsive to the global tendency in favour of arbitration of price revision claims. This phenomenon can be explained in a number of ways.

The first, and arguably most important, reason for the lack of price review arbitrations in Asia is a limited number of price review disputes to date which would lend themselves for resolution by arbitration. Considering that the practice of including price review clauses in long-term Asian SPAs dates back to the 1990s, and most older contracts stipulated price review periods spanning over ten years, the first opportunities to trigger price reviews on the basis of these clauses emerged only in the last decade. As discussed below, at least in some of these cases, parties willing to commence arbitration could have encountered a contractual barrier (like the lack of an arbitration clause) effectively preventing them from pursuing the arbitration route. In some other cases, the parties could well have been able to settle their case with no need to pursue any formal dispute resolution procedure.

The second reason for the lack of widespread use of arbitration for Asian LNG pricing disputes might be the traditional Asian preference for resolving disputes out of court, 'in a spirit of mutual understanding and trust' (Sullivan, 2017, 185). The Japanese, in particular, are generally seen as 'non-litigious people', who have 'an unusual and deeply rooted preference for informal, meditated settlement of private disputes and... do not take advantage of the available mechanism for formal dispute resolution' (Haley, 1978, 359).

The third consideration which has, potentially, decreased the number of Asian LNG price review arbitrations to date, is the perception that the commencement of arbitration is detrimental to a longterm business relationship between the parties. The following statement is reflective of this position: 'Maintaining a good relationship between buyer and seller is an important factor in preventing disputes having to be settled through arbitration' (Flower and Liao, 2012, 372).

Other reasons include a general impression of some of the drawbacks of gas price review arbitration, which mainly relies on anecdotal evidence from European cases. Industry input strongly suggests that the key criticism in relation to gas price review arbitration is the perceived freedom of arbitrators to rewrite the price formula in an uncontrolled manner. In particular, it is widely feared that arbitrators

\footnotetext{
${ }^{69} \mathrm{https}: / /$ globalarbitrationreview.com/article/1031603/edison-awarded-gas-price-discount.

$70 \mathrm{https}: / /$ www.mcnairchambers.com/client/publications/2013/LNG_PRICE_REVIEW_DISPUTES_.pdf.

${ }^{71}$ https://www.lexology.com/library/detail.aspx?g=1d775cb2-c99f-4019-b142-214731b8e828.

72 Some other sectors, for example technology or financial sector, have been traditionally reluctant to use arbitration and have favoured litigation before national courts.

${ }^{73}$ Some other types of disputes, and non-contractual disputes in particular, are considered to be less suited for arbitration.
} 

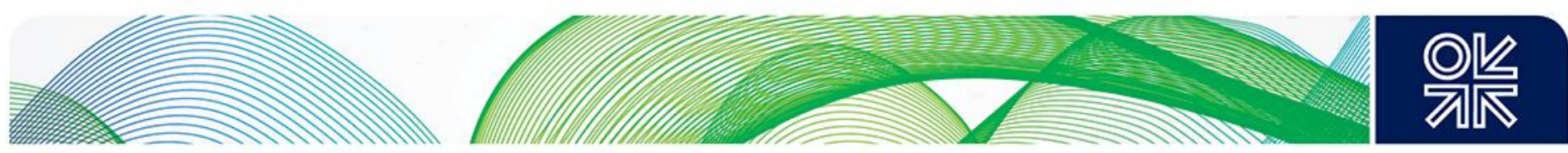

could introduce a novel pricing structure of their own design, or replace the oil link with some alternative index, in the absence of such a request from either party. This largely rests on experience from the Atlantic LNG case where a tribunal applied a dual pricing formula which 'neither party had requested and both appear to have argued against' (Griffin, 2017, 115). Apart from the prospect of unwanted results in gas pricing disputes, industry evidence highlights some general concerns in relation to arbitration, including the perceived complexity, excessive length, and cost of arbitral proceedings.

\subsection{The potential for LNG price review arbitrations in Asia}

The number of LNG pricing arbitrations in Asia is likely to increase. However, this is not due to a similarity between market transition patterns in Europe and Asia, which would offer a reason to believe that the European experience with gas pricing arbitrations may be repeated in an Asian LNG context in the coming years (as it is often claimed). ${ }^{74}$ Rather, LNG pricing arbitrations in Asia can be expected to follow a distinct path and will originate primarily from future reshuffles to pre-established regional market fundamentals, contractual arrangements, and dispute resolution preferences. Five factors, in particular, speak in favour of the growing role of arbitration in disputes resulting from the Asian LNG contracts.

\section{Changing nature of the LNG sector}

While the first decades of LNG history where dominated by a limited circle of actors, the global expansion of LNG trading has opened the industry to many more participants. Although the Asian LNG industry remains a closely-knit sector, the growing role of emerging international players is likely to loosen the tight connections, and traditional interdependence, between the most established buyers and sellers. The growing role of international lenders and trading houses, in particular, can be expected to lead to a greater push towards price review clauses providing for arbitration in the case of failure of good faith discussions. The arbitration option is likely to be requested by lenders mainly for the sake of legal certainty, and especially as a means to minimize their exposure to the risk of protracted pricing negotiations and to secure operational continuity of the contract. For the same reasons, international trading houses, increasingly acting as buyers and sellers of Asian LNG, are likely to insist on arbitration, which they otherwise use for a variety of international commercial and investment disputes. ${ }^{75}$

Generally, the growing involvement of players who consider arbitration as an ordinary part of the business may alter the pervasive misconception in the LNG industry that arbitration is detrimental to the relationship between the parties. As evidenced by experience from the broader oil and gas sector, even a significant portfolio of pending arbitrations between two companies does not preclude their new deals, or a good business relationship. ${ }^{76}$ Notably, Woodside Petroleum signed a Memorandum of Understanding with KOGAS for the development of the Port Arthur project after KOGAS commenced arbitration against the North West Shelf Joint Venture. The CEO of Woodside Petroleum stated, at that time, that the 'relationship with KOGAS is still a good one ... and arbitration is just the final natural completion point for [the dispute]. ${ }^{77}$ Arbitration is, indeed, increasingly seen as a natural final part of the dispute resolution process. Importantly, the decision to file for arbitration does not prevent, or discourage, amicable settlement. Efforts to settle a dispute may well continue in parallel with the

\footnotetext{
${ }^{74}$ See, for example, Lee (2018), and Terceño, Phua, and Stennett (2018), who point to 'strong similarities' between the current Asian markets and the conditions previously present in European markets that resulted in a wave of price reviews and arbitrations in Europe.

${ }^{75}$ Most trading houses which are active in the LNG sector can be expected to have pending arbitrations, including against states. Some of these cases are in the public domain. For example, recently, Trafigura commenced arbitrations against Benin and Papua New Guinea, and Gunvor against Zambia.

${ }^{76}$ In the oil sector in particular, large-scale arbitrations tend to involve repeated players who interchangeably assume roles of claimants or respondents (depending on a particular case) and otherwise continue to cooperate.

77 Transcript from an open briefing session held on 14 February 2018 at Woodside Petroleum Ltd., available at https://files.woodside/docs/default-source/investor-documents/quarterly-and-half-yearly-pdfs-and-data-tables/2017/15-02-20182017-fy-results-and-entitlement-offer---media-teleconference-transcr.pdf?sfvrsn=7c8b9256 11.
} 

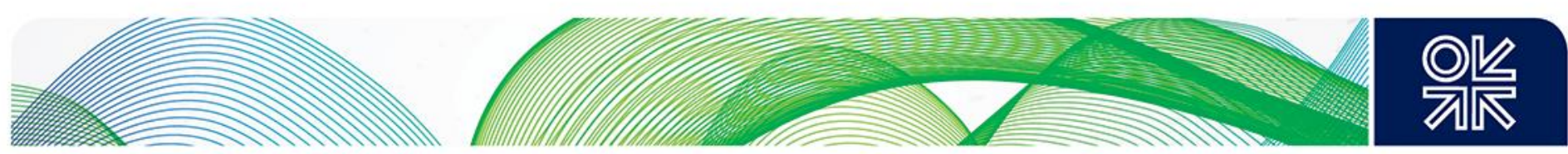

arbitration and are, in fact, likely to become more successful as the case unfolds and new evidence is admitted, and the parties have the opportunity to test the strength of their case.

\section{Increasing sophistication of price review clauses}

As soon as Asian LNG buyers and sellers develop a more systematic approach to price reviews, this is likely to be reflected in the content of price review clauses. To recap, these originally offered little guidance as to the particularities of the price review. As the practical experience of operating price reopeners is set to increase, price review clauses will likely receive more attention during contract negotiations and, inevitably, become more specific in nature. Apart from substantive conditions for the price review, they will need to address procedural issues. Although negotiations are likely to remain the starting point for price review discussions, they are unlikely to remain the only avenue for a price review request. Instead, the parties to Asian LNG contracts will be able consider several options for price review processes in their new or amended contracts. Considering that there is no clear pattern of preference for any particular third-party dispute resolution mechanism in Asian LNG contracts, rather than adopting the option of arbitration, parties may choose to terminate the contract.

\section{Expansion of arbitration in Asia}

The general Asian attitude towards dispute resolution has significantly changed in the past few years. Notwithstanding the traditional preference for informal, 'non-litigious', methods, arbitration is now rapidly expanding in Asia. Several countries in the Asia-Pacific, including Singapore, Hong Kong, Japan, and China, have significantly improved their arbitration regulatory frameworks, ${ }^{78}$ and are home to thriving arbitral institutions. Singapore, in particular, originally 'a strong favourite for choice of seat for oil and gas disputes among parties from China, Indonesia and India' (Mulcahy, 2015, 286), is becoming a global dispute resolution hub, and the Singapore International Arbitration Centre (SIAC) keeps reporting record-breaking caseload statistics. ${ }^{79}$

In parallel with Asia becoming an attractive venue for international disputes, Asian parties are increasingly using arbitration. Some cases involving Asian energy companies are in the public domain. For example, in 2016, Sinopec filed a $\$ 5.5$ billion claim against Repsol in Singapore over an investment in an ailing North Sea oil joint venture. In 2017, PetroChina (and five other Chinese stateowned oil companies) commenced arbitration over oil and gas fields in Chad against Carlton, a Texas energy investments firm. At that time, MedcoEnergi, an Indonesian oil company, won a US\$24 million award in a dispute with Singaporean and Australian partners arising out of a joint venture to operate an oil field off the coast of East Java (Speller, Lim, and Li, 2019, 32). More recently, Korean South East Power Company filed a $\$ 7.5$ million arbitration claim under SIAC Rules over the construction of a coal-based power plant, against its Indian partner, which responded to the claim with a $\$ 600$ million counterclaim. ${ }^{80}$

Asian energy companies are also increasingly seeking recourse to arbitration against states. The past few years have seen investment treaty claims filed by Chinese, Korean, and Malaysian investors. Notably, Japanese companies are also beginning to take advantage of their rights under international investment treaties. For example, in July 2018, Itochu Corporation, a Japanese renewable energy investor, commenced arbitration against Spain under the Energy Charter Treaty, ${ }^{81}$ the world's preeminent energy sector-specific investment treaty, to which Japan is a party. Potentially, the same route of recourse would be available to foreign investors in the Japanese LNG sector, or to Japanese LNG companies investing in countries which ratified the Energy Charter Treaty, like United Kingdom or Germany. The Energy Charter Treaty is likely to become more relevant as a basis for investment

\footnotetext{
${ }^{78}$ All Asian LNG countries (with the sole exception of Taiwan) have ratified the New York Convention.

${ }^{79} \mathrm{https}$ ://globalarbitrationreview.com/article/1181225/siac-releases-latest-case-figures.

${ }^{80} \mathrm{https}$ ://globalarbitrationreview.com/article/1159105/indian-and-east-asian-companies-battle-it-out

${ }^{81}$ https://globalarbitrationreview.com/article/1172045/spain-faces-solar-claim-from-japanese-company.
} 

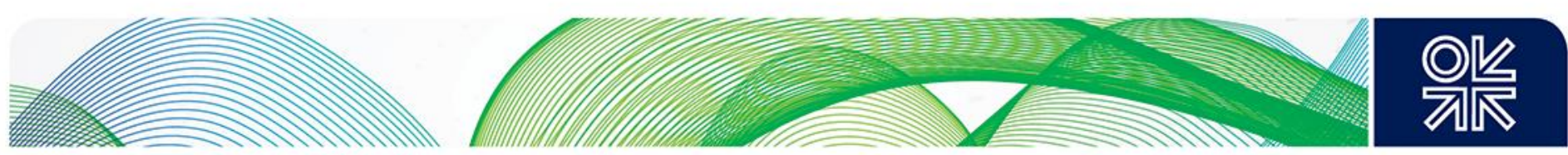

treaty claims in the LNG sector due to anticipated accession to the Treaty of other key Asian LNG countries, including China and South Korea. 82

\section{Innovations in arbitration}

Arbitration, as a dispute resolution process, is constantly improving. Several innovative mechanisms have been recently introduced to strengthen the time- and cost-efficiency of the arbitral process. For example, SIAC Rules now offer a mechanism for summary dismissal of unmeritorious claims and defences ${ }^{83}$, which, in essence, allows for an early strike-out of submissions manifestly lacking legal merit. To avoid delays in the decision-making process, arbitral rules increasingly specify time limits for arbitrators to render an award. ${ }^{84}$ Furthermore, third-party funding in arbitration is rapidly expanding, providing an alternative source of financing for an arbitration claim, and opening the arbitration route to companies in financial distress. Technological advancement is also taking off in arbitration and offers a promise of significant cost savings, moving traditional components of the arbitral process to the digital sphere of 'e-disclosure, e-case management or e-hearings. ${ }^{\prime} 5$

\section{Lessons from European gas price reviews}

Although it is certain that gas price review arbitrations in Asia will not be an 'identical replay' of European arbitrations, ${ }^{86}$ the questions in Asian arbitrations will likely be of a similar nature to those that arose in Europe. Having the advantage of lessons learned over several decades of gas price review arbitrations in Europe, Asian stakeholders are in a privileged position. Certainly, they do not need to venture into the unknown, and can take advantage of a robust, time-tested, and improved, dispute resolution mechanism. Even so, the arbitration of Asian LNG price review disputes is unlikely to be a smooth exercise. Rather, it can be expected to involve both unique, region-specific, hurdles and some pervasive problems encountered in the earlier price review arbitrations. Ideally, a dispute resolution strategy will take account of both perspectives well in advance.

\section{Key considerations in arbitration of Asian LNG pricing disputes}

\subsection{Arbitration clause}

\section{Availability of arbitration route in existing contracts}

Asian LNG supply agreements vary widely in terms of availability of a clear contractual basis for arbitration. Only a limited number of price reopeners will expressly refer the parties to arbitration in the event of their failure to agree in price review discussions. Rather, the party contemplating arbitration is likely to face a dilemma as to whether a general arbitration clause set out elsewhere in the SPA and stipulating, for example, that 'any disputes arising out of this agreement shall be resolved by arbitration,' can be used as a basis for the price revision arbitration claim. This will largely depend on the wording of both price review and arbitration clauses, their enforceability, and mutual consistency. The assessment of these factors will mostly depend on applicable law, which, in Asian LNG contracts, is 'inevitably' English or New York law (Davis, 2014, 31).

For example, if a contract is governed by English law, and the price review clause only obliges the parties to engage in good faith discussions, it may be difficult to persuade the tribunal that it has jurisdiction. ${ }^{87}$ The task would be even more challenging where there is an inherent incompatibility

\footnotetext{
${ }^{82}$ For a discussion of the scope of protection of LNG investments under the Energy Charter Treaty, see Maynard and Ason (2019).

83 SIAC Arbitration Rules, Rule 29

${ }^{84}$ For example, under SIAC Rules the tribunal needs to submit the award in draft form to the Registrar within 45 days after the closure of the proceedings (Rule 32.3).

85 https://globalarbitrationreview.com/article/1172902/overcoming-reluctance-to-arbitrate-in-the-tmt-sector.

86 The phrase is taken from van Geuns $(2016,2)$, who makes this point in relation to Asian, as compared to European, gas price reviews, noting that 'both the contractual situation and market are too different for that.'

${ }^{87}$ For a discussion of agreements to negotiate in good faith under English law, see Leggatt (2018).
} 

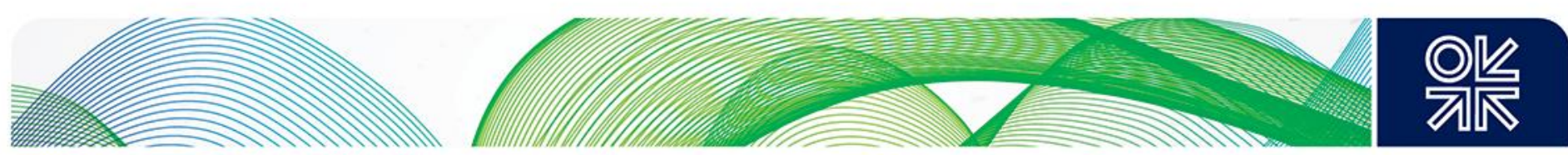

between dispute resolution provisions in price review and arbitration clauses, the contract does not contain an arbitration clause, or explicitly provides for another option after failed negotiations, like expert determination, or contract termination. In some cases, arbitration would require a separate agreement between the parties, or amendment to the LNG contract which, practically speaking, could prove difficult to achieve.

It should be noted that even the, arguably, most straightforward option of a price review clause explicitly referring the parties to arbitration can prove problematic. Arbitration clauses, sometimes labelled as 'champagne clauses', are often inserted hastily at the end of contract negotiations. Even in high-stakes deals, they can involve different types of flaws, including ambiguities, contradictions, or omissions, which can later either compromise or slow down the arbitral process. For example, it may be unclear whether pre-arbitration steps are mandatory, where the arbitration should be seated, or which law applies to the contract. All these, and similar issues, may result in ancillary disputes.

Notably, the risk of unenforceable or otherwise pathological arbitration clauses can be expected to be higher in the Asian LNG context, where all outcomes were reached through negotiations, and the wording of arbitration clauses has not been tested in practice. Therefore, for some existing contracts, the decision to pursue an arbitration route is likely to be weighed against the risks of disputes resulting from an arbitration clause, which would potentially need to be resolved in separate proceedings before national courts.

\section{Careful drafting in new contracts}

Parties contemplating an arbitration option in newly arranged, or renegotiated contracts, are in a position to eradicate most risks resulting from arbitration clauses well in advance. Careful drafting should ensure that the conditions for arbitration will be sufficiently clear, flexible, and consistent.

Apart from standard features found in most arbitration clauses (specifying, in the first place, arbitral rules, the seat of arbitration, and the number of arbitrators), the parties to Asian LNG contracts can introduce some additional provisions to strengthen the efficiency of the process. For example, the parties can agree that the proceedings will be 'bifurcated', that is divided into different phases, so that the tribunal will first deal with the trigger for price review and only then consider the issue of price adjustment. Moreover, the parties may specify time limits for arbitrators to render an award, determine scope of discovery, or agree in advance on the appropriate method of cost allocation. Some further elements can be contemplated, including expectations towards the number of rounds of written and oral pleadings, location of hearings, or technology support in arbitration. However, all less common additions to arbitration clauses need to be well-thought-out, so that they simplify, rather than complicate, the arbitral process, ${ }^{88}$ and, most importantly, do not lead to ancillary disputes.

\subsection{The powers of arbitrators}

In the arbitration clause (or elsewhere), the parties may also specify the powers of arbitrators in a price review. To recap, the threat that arbitrators could rewrite the price formula in an uncontrolled manner is the key complaint raised in relation to gas price review arbitrations. This fear possibly rests on a false assumption that the power of arbitrators originates from some source that is beyond the control of the parties. Notably, in contrast to national judges, arbitrators do not take their mandate from any external act. Rather, an arbitration clause agreed by the parties is what makes an arbitrator an arbitrator. Accordingly, the powers of an arbitrator are defined, and can be restrained, by the parties to the contract. The usual recommended strategy to mitigate the risks of unwanted results is 'baseball arbitration', which essentially reduces the task of arbitrators to a binary choice between two pricing proposals submitted by the parties. ${ }^{89}$ Baseball arbitration found little, if any, acceptance in the

\footnotetext{
${ }^{88}$ Logistical issues, in particular, are better suited for a discussion at early stages of arbitration (for example, at the case management conference)

${ }^{89}$ See, for example, Tevendale and Morgan $(2017,11)$, who note that the adoption of baseball arbitration 'should encourage the parties to submit more cautious and readily justifiable proposals regarding the meaning of the price review clause and their proposed revised contract price.
} 

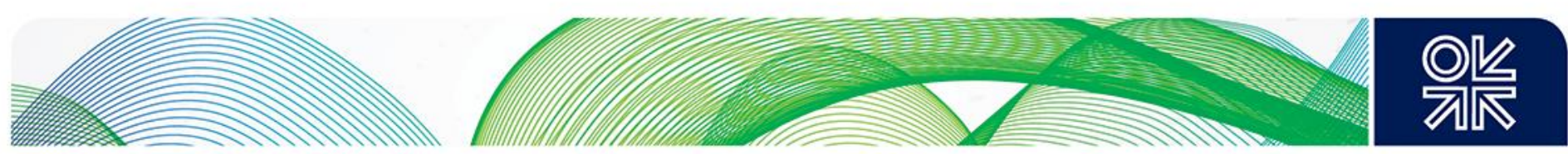

industry. ${ }^{90}$ This is unsurprising. Extreme solutions are not needed to give the parties more control of the price review process. A wide variety of other measures can be adopted to limit the discretion of an arbitral tribunal hearing a price review claim. At the same time, it is essential to leave arbitrators sufficient flexibility, so that overly prescriptive limits do not restrain their ability to provide a commercially sound decision that reflects a market price. Some strategies, which are arguably most suited for Asian LNG contracts, are discussed below.

\section{Limits to the decision-making process of arbitrators}

First, the parties can instruct arbitrators as to how they should (or should not) arrive at their decision. To that end, they can specify factors to be considered, or types of evidence to be excluded, in the price review. They can also offer arbitrators clear guidance as to the acceptable economic result of price adjustment. The parties may also set a threshold on retroactivity, and the relevant time perspective, of the price review and define, for example, to what extent the future impact of changes to the price should be relevant to a decision on the revision of the contract price.

\section{Limits to structural changes to the price formula}

In addition, or in the alternative, the parties may limit structural changes to their price formula. The parties to Asian LNG contracts may be inclined to reserve wholesale structural changes to a limited set of circumstances. For example, they can allow for a complete change of price formation in the event of a gas hub being created in either the buyer's market or the region (Stern, 2016a, 490), or allow for such a change only when a specified level of liquidity of the gas hub is achieved. ${ }^{91}$ Furthermore, the parties can restrain the power of arbitrators to change the slope, constant, oil benchmark, or any other components of the price formula. They may also expressly exclude the application of specific indexes like JKM or Henry Hub.

\section{Quantitative limits to the revision of the contract price}

Parties willing to limit the discretion of arbitrators in the most tangible manner as to the expected financial result, may insert a range by which the tribunal is able to increase or decrease the contract price. To that end, the contract can refer the arbitrators to either specific high-low figures, or a percentage of an acceptable change, or stipulate transition to a new price formula over a period of years (so that, instead of making the price change immediately, arbitrators establish a new basis for pricing and allow for it to be introduced gradually). These (or other) quantitative limits can feature in isolation, or accompany the limits concerning the decision-making process of the tribunal or the scope of allowed structural changes to the price formula.

\subsection{The role of experts}

Experts play a key role in gas price review arbitrations (Gibson and Moselle, 2014, 118). They primarily offer input on market fundamentals and pricing mechanisms. Expert evidence in gas price review arbitrations often runs into hundreds of pages and legal submissions 'largely track the expert evidence' (Levy, 2019, 213). Experts can be appointed by the parties or the tribunal.

Especially at the price adjustment stage, the tribunal is likely to seek the assistance of a tribunalappointed expert. If the tribunal informs the parties that it requires such assistance, this request will likely trigger the following process: first, the tribunal will invite the parties to comment on the general principle and specific conditions of appointment of an expert. After the exchange of written submission on these issues, and in the absence of objections to the appointment of an expert, the tribunal will suggest that the parties may agree on a list of three potential candidates. The tribunal will either receive this list or, if not provided, embark on its own search for a suitable candidate. The tribunal will then interview the candidates and inform the parties about the selection, offering them an opportunity to comment on the appointment. If there are no objections, the tribunal will appoint the expert and

\footnotetext{
${ }^{90}$ Author's research.

${ }^{91}$ The price review clause could refer to a specific Churn rate.
} 

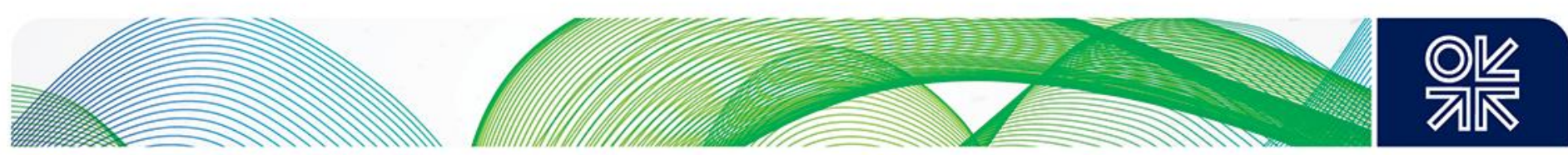

define his or her mandate. The tribunal will then meet with the expert, and the expert will prepare and submit a report. Having received the report, the parties will call the expert for cross-examination. For that purpose, the parties, the expert, and the tribunal, will typically meet for an expert hearing. After the hearing, and the exchange of post-hearing submissions, the tribunal will communicate its decision as to the revised price formula.

The whole process will typically take several months to complete, and can be expected to last for over a year if it involves challenges to an expert brought by either party, or the appointment of a second expert by the tribunal. In some cases, the involvement of tribunal-appointed experts at the adjustment stage will result in multiple expert reports accompanied by several rounds of written submissions, meetings with the tribunal, and oral hearings. Although the tribunal is likely to emphasise from the outset that the mandate of the tribunal-appointed expert is strictly limited to a specific question, and the expert 'will not act as an arbitrator', the practical reality is that arbitrators rarely, if ever, make their decisions without substantial input from an expert who will guide them through the particularities and financial consequences of price adjustment. In some cases, a tribunal may so heavily rely on expert evidence in the determination of the contract price that 'a tribunal-appointed expert may become the de facto decision maker in the dispute' (Mourre, 2006). This, in turn, will be reflected in the costs of arbitration. In order to obtain a decision on price adjustment, the parties will need to pay the fees of arbitrators, the decision-makers and experts, being de facto decision makers, who formally only assist the tribunal.

\section{An idea: post-arbitration expert determination}

An alternative approach to the excessive reliance of arbitrators on expert evidence in price determination would be a formal change of the decision-maker at the price adjustment stage. Essentially, this would mean that the third-party dispute resolution process will be divided into two phases: arbitration and post-arbitration expert determination. In the first (arbitration) phase, arbitrators will consider procedural and substantive conditions for a price review. If these are met, in the second (expert determination) phase, the expert (or panel of experts) appointed by the parties, will determine the revised price. This allocation of tasks will mean that the legal aspects, involving complex issues of contract interpretation, are within the jurisdiction of arbitrators, while price calculation, which requires expert knowledge, is reserved for expert determination.

This twist on bifurcation (as seen in arbitration) takes the decision on the determination of the price away from the arbitrators and puts it in the hands of an expert. Like the mandate of an arbitrator, the mandate of an expert is defined by the parties to the contract. It could, therefore, be restrained by the parties in a similar manner, as discussed above, and be subject to some specified limits. It might well be that the parties entrusting the expert, who is well-versed in international gas markets and familiar with the intricacies of the LNG business, with the decision as to the contract price would be inclined to leave him/her more discretion, so that the determination of the contract price in the most appropriate commercial manner is not restrained by any predefined structural, or other, limits. Clearly, the parties would be able to set stricter time limits for the determination of the price by an expert.

\section{Summary and conclusions}

Although market conditions trigger price reviews, contractual barriers can well prevent them. The lack, and limitations, of price review clauses in Asian LNG contracts historically translated into a low number of revisions to prices under long-term contracts in the Asian markets. Contracts finalized in recent years typically contain price reopeners and stipulate more flexible conditions for a price review request (including shorter price review periods). LNG SPAs concluded in the 2000s, which accepted a close link to oil prices in particular, are naturally exposed to price reviews. Considering that these contracts can be expected to contain new-generation price reopeners, Asian LNG markets might be now entering into an unprecedented period of price renegotiations. Japanese buyers have always been, and are likely to remain (at least volume-wise) at the forefront of Asian price reviews. However, these are not limited to any particular region in Asia, and can be expected to occur in both established 

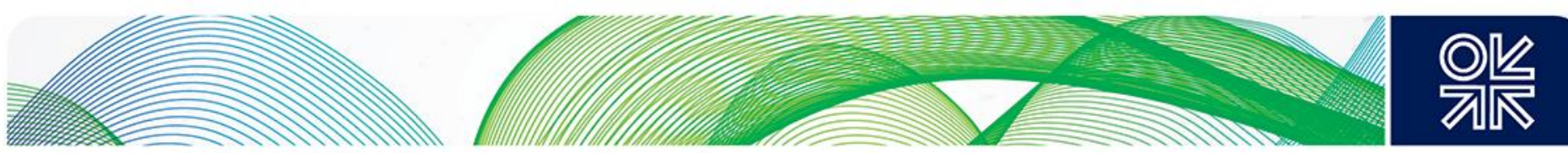

and emerging LNG markets. Buyers in the markets with the strongest long-term prospects for LNG growth are likely to have the strongest bargaining power in future price renegotiations. Arbitration, the preferred method of dispute resolution in European gas pricing disputes, is likely to become an important, novel, addition to the Asian LNG price review landscape. Arbitration of Asian LNG pricing disputes is unlikely to be a smooth exercise. Rather, it can be expected to involve both unique, region-specific, hurdles and some pervasive problems encountered in earlier price review arbitrations. In comparison to their European counterparts, Asian buyers and sellers contemplating arbitration for their contracts are in a privileged position. In particular, they do not need to venture into the unknown and can capitalize on lessons learned over several decades of handling gas price review arbitrations in Europe. Offered with a robust, time-tested, and improved, dispute resolution mechanism, they can tailor arbitration to their needs and use it primarily to hedge against the risks of protracted price review discussions. 

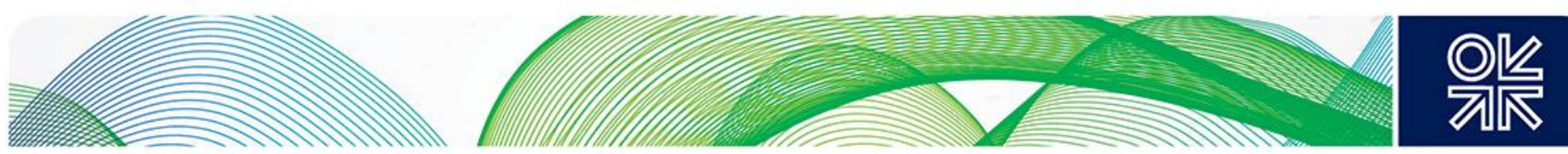

\section{Glossary}

$\begin{array}{ll}\text { ADGAS } & \text { Abu Dhabi Gas Liquefaction Company } \\ \text { bbl } & \text { barrel } \\ \text { CNOOC } & \text { China National Offshore Oil Corporation } \\ \text { CNPC } & \text { China National Petroleum Corporation } \\ \text { constant } & \text { A component of an oil-linked linked price formula in Asian LNG contracts which adds } \\ & \text { a fixed amount to the contract price } \\ \text { GAIL } & \text { Gas Authority of India Limited } \\ \text { ICC } & \text { International Chamber of Commerce } \\ \text { ICP } & \text { Indonesian Crude Price } \\ \text { JCC } & \text { Japan Customs-cleared Crude Oil Price, also known as 'Japanese Crude Cocktail' } \\ \text { JKM } & \text { Japan Korea Marker (spot LNG price published by Platts) } \\ \text { KOGAS } & \text { Korea Gas Corporation } \\ \text { LNG } & \text { Liquefied natural gas } \\ \text { mtpa } & \text { Million tonnes per annum } \\ \text { NBP } & \text { National Balancing Point } \\ \text { POSCO } & \text { formerly known as Pohang Iron and Steel Company } \\ \text { SIAC } & \text { Singapore International Arbitration Centre } \\ \text { Slope } & \text { A component of an oil-linked price formula in Asian LNG contracts (in the Atlantic } \\ & \text { Basin known as 'index') which is typically expressed as a percentage and determines } \\ \text { how the LNG price changes in response to changes in oil prices }\end{array}$



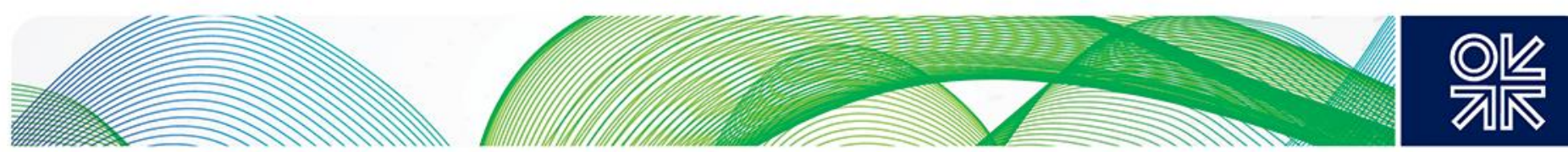

\section{Bibliography}

Anway, S. and von Mehren, G.M. (2019). 'The Evolution of Gas Price Review Arbitrations', in Rowley, J.W. (ed.), The Guide to Energy Arbitrations, Global Arbitration Review (3rd edition).

Arif, M. (2017). 'Future of LNG in Pakistan' Oil, Gas \& Energy Law, (15), 4.

Baily, J. and Lidgate, R. (2017).'LNG - a minefield for disputes?' in Griffin, P. (ed.), Liquefied Natural Gas: The Law and Business of LNG, Globe Business Publishing (3rd edition), 305.

Bohmer, L. (2015). 'Arbitrating international LNG disputes: lessons learned over two decades', Journal of World Energy Law and Business, (8), 5.

Christie, K. and Ogut, E. (2017). 'The Interplay of Force Majeure and Change of Circumstances with Dispute Resolution Clauses in Modern Long-term LNG Contracts - What Role for A Price Review Clause?', Oil, Gas \& Energy Law, (15), 4.

Davis, P. (2014). 'Renegotiating Long-Term Energy Supply Contracts with Japanese Buyers', Journal of Japanese Law, (38), 29.

Dargin, J. and Flower, A. (2011). 'The UAE Gas Sector', in Fattouh, B. and Stern, J.P. (eds.), Natural Gas Markets in the Middle East and North Africa, Oxford: OUP/OIES.

Flower, A. and Liao, J. (2012). 'LNG pricing in Asia', in Stern, J.P. (ed.), The Pricing of Internationally Traded Gas, Oxford: OUP/OIES.

Gibson, C. and Moselle, B. (2014). 'The role of the expert in price review arbitrations' in Levy, M. (ed.), Gas Price Arbitrations: A Practical Handbook, Globe Business Publishing, 117.

Griffin, P. and van Eupen, F. (2014). 'The Future for Price Reviews', in Levy, M. (ed.), Gas Price Arbitrations: A Practical Handbook, Globe Business Publishing, 141.

Griffin, P. (2017). 'Principles of price reviews and hardship clauses in long-term gas contracts', in Griffin, P. (ed.), Liquefied Natural Gas: The Law and Business of LNG, Globe Business Publishing (3rd edition), 89.

Haley, J.O. (1978). 'The Myth of the Reluctant Litigant', Journal of Japanese Studies, (4), 2.

Lau, L. (2014). 'Price reviews in the Asian LNG market', International Energy Law Review, (32), 8.

Lee, S. (2018). 'Asia: The new battleground for gas price reviews?', Commercial Dispute Resolution.

Leggatt, G. (2018). 'Negotiation in Good Faith: Adapting to Changing Circumstances in Contracts and English Contract Law', Jill Poole Memorial Lecture (19 October 2018).

Levy, M. (2019). 'Gas Price Review Arbitrations: Certain Distinctive Characteristics', in Rowley, J.W. (ed.), The Guide to Energy Arbitrations, Global Arbitration Review (3rd edition), 209.

Maynard, S. and Ason, A. (2019). 'Is the Energy Charter Treaty Ready to Embrace Energy Transition?' Transnational Dispute Management (1). 

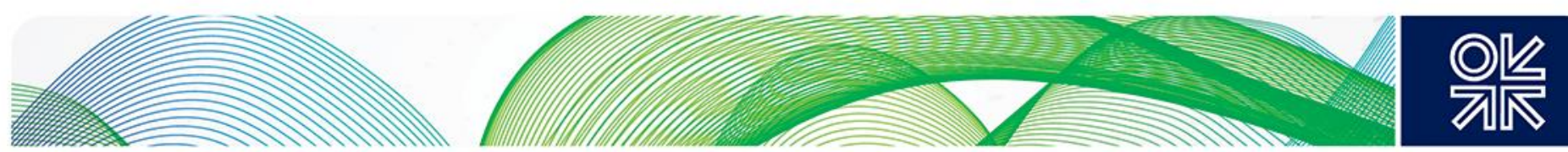

Mourre, A. (2006). 'Gas Price Reopeners: is Arbitration Still the Answer?', Dispute Resolution International, (9), 2.

Mulcahy, C. (2015). 'The changing face of disputes in the liquefied natural gas market', Journal of Energy \& Natural Resources Law, 33 (3), 271.

Oghigian, H., Henneberry, L.G., and Jones, J. (2017). 'LNG Contracts in the Asia-Pacific Region: Disputes on The Horizon?', Oil, Gas \& Energy Law (4).

Speller, D., Lim, J., and Li, J. (2019). 'Oil and Gas Arbitration in the Asia-Pacific Region', The AsiaPacific Arbitration Review 2019, 30.

Stern, J.P. (2016a). 'LNG Pricing: challenges in the late 2010s', in Corbeau, A-S. and Ledesma, D. (eds.), LNG Markets in Transition: The Great Reconfiguration, Oxford: OUP/OIES.

Stern, J.P. (2016b). 'The new Japanese LNG strategy: a major step towards hub-based gas pricing in Asia.' OIES.

Stern, J.P. and Koyama, K. (2016). 'Looking back at history: the early development of LNG supplies and markets', in Corbeau, A-S. and Ledesma, D. (eds.), LNG Markets in Transition: The Great Reconfiguration, Oxford: OUP/OIES.

Sullivan, H.W. (2017). 'LNG sale and purchase agreements', in Griffin, P. (ed.), Liquefied Natural Gas: The Law and Business of LNG, Globe Business Publishing (3 $3^{\text {rd }}$ edition), 185.

Terceño, J.P., Phua, D., and Stennett, E. (2018), 'The LNG View: Gas-Pricing Disputes Coming to Asia', Transnational Dispute Management, 15 (7).

Tevendale, C. and Morgan, C. (2017). 'Making the Most of Arbitration as a Tailored Mechanism for Resolving LNG Disputes', Oil, Gas \& Energy Law, (15), 4.

Trimble, N. (2018). 'Changing LNG markets and contracts', Journal of World Energy Law and Business (11), 427.

Van Geuns, E. (2016). 'The Dawn of LNG Price Reviews in Asia Pacific', Journal of the Australian Petroleum Production \& Exploration Association, 56.

Weems, P. R. (2006). 'Evolution of long-term LNG sales contracts. Trends and issues', Oil, Gas, and Energy Law 4 (1). 